\title{
PENGUKURAN PERFORMA ALGORITMA KENDALI KONGESTI ACTIVE QUEUE MANAGEMENT (AQM) PADA JARINGAN BACKBONE MULTICAST BERBASIS PROTOCOL Multicast PIM-DM
}

\section{Performance Measurement of Active Queue Management (AQM) Congestion Control Algorithm in Multicast Backbone Network Based on PIM-DM Multicast Protocol}

\author{
Rizka Ardiansyah \\ Jurusan Teknologi Informasi, Fakultas Teknik, Universitas Tadulako \\ e-mail: rizka@untad.ac.id / ardiansyah.rizka@gmail.com
}

Received 12 / 11 / 2018, Revised 22 / 11 / 2018, Accepted 24 / 11 / 2018

\begin{abstract}
UDP is a data transmission protocol on the Internet that allows data to be sent in realtime and become a development base of various services such as IPTV, VOIP, VOD, and video conferencing. The multicast network was a solution to provide better service to many public needs with the concept of simplicity and efficiency. Dense traffic situation triggering a packet loss and delay that not tolerated by some services, especially multimedia streaming service, while UDP does not guarantee the quality of service so that the necessary traffic management method that serves as a traffic controller to the congestion in the network. This study analyzes the performance of technology based on Active Queue Management (AQM) congestion control in a multicast backbone network based on Protocol Independent Multicast - Dense Multicast using Droptail, Deficit Round Robin (DRR), and Random Early Detection (RED) algorithm, which is simulated using NS2. The simulation results show that the congestion control algorithm, DRR provides the best performance with a balanced value of mean delay, mean throughput, and the mean loss. RED is a congestion control algorithm which has the best queue management mechanism but not able to suppress the mean loss in each scenario tested because RED has a small amount of buffer size, Droptail not an appropriate algorithm for multicast networks implemented in, the absence of an interrupt mechanism trigger data services will have a tendency towards a particular data packet.
\end{abstract}

keywords - Congestion Control, AQM, DRR, Droptail, RED

\section{Pendahuluan}

Perkembangan internet sudah semakin pesat bukan hanya paket data kecil yang dapat dibawa melalui jaringan internet, melainkan paket data besar seperti transfer video dan suara secara bersamaan kini telah dapat dilewatkan melalui jaringan internet. Perkembangan ini berbanding lurus dengan banyaknya pengguna jasa layanan internet. Meningkatnya penggunaan dan popularitas dari internet maka meningkat pula perkembangan aplikasi-aplikasi baru yang muncul seperti voice, video dan web. Peningkatan ini menyebabkan adanya beban yang signifikan pada jaringan yang memiliki bandwidth yang terbatas, hal inilah yang memicu terjadinya kongesti [1].

UDP merupakan tulang punggung protocol pengiriman data di Internet [2]. Protocol UDP yang memungkinkan data dapat dikirim secara realtime serta menjadi cikal bakal lahirnya berbagai layanan seperti IP Television, VOIP (Voice Over Internet Protocol), VOD (Video On Demand), serta video conference. Berbagai layanan tersebut kini menjadi konsumsi publik secara luas, sehingga 
sarana dan prasana jaringanpun diharuskan menyesuaikan dengan kebutuhan publik, maka tidak heran jika saat ini konsep jaringan multicast adalah solusi untuk memberi pelayanan yang lebih baik terhadap kebutuhan publik tersebut. Menurut Prasetya [3] Universal Datagram Protocol (UDP) tidak menjamin Quality of Service (QOS) dari layanannya, sementara konsep jaringan multicast yang saat ini banyak digunakan sebagai media bagi layanan-layanan berbasis UDP sangat sensitif terhadap kongesti yang memungkinkan menurunnya kualitas data yang diterima oleh end user. Keadaan traffic jaringan adalah salah satu faktor yang mempengaruhi kualitas layanan aplikasi internet khususnya pada jaringan multicast [2]. Keadaan traffic yang padat dan tidak terkontrol akan memicu terjadinya paket loss, dan delay yang tentunya sangat tidak dapat ditolelir oleh beberapa layanan khususnya layanan multimedia streaming, sehingga dibutuhkan suatu metode management traffic yang berfungsi sebagai pengontrol traffic terhadap kemacetan (congestion control) yang terjadi dalam jaringan. Transmisi paket melalui media pada setiap waktu memerlukan pengolahan rutin paket [2] Saat ini teknik yang digunakan dalam pengendalian congesti masih berdasarkan Additive Increase Multiplicative Decrease (AIMD) yang diimplikasikan dalam TCP, metode ini melibatkan umpan balik implisit atau eksplisit. Saat tidak ada congesti jumlah data yang dikirim meningkat sementara jika terjadi congesti jumlah data yang dikirim akan diturunkan menunggu hingga jaringan telah bebas dari congesti. Metode seperti ini sekalipun mampu menekan paket loss namun akan mengakibatkan delay yang cukup besar dan pada layanan tertentu seperti halnya multimedia streaming, hal ini tidak dapat ditolelir. Metode active queue management congestion control merupakan metode pengontrolan terhadap kongesti yang berbasis pada tiap router jaringan. Active queue management berkerja secara realtime pada tiap line router memonitor dan mengatur setiap data yang akan melintas, serta melakukan management terhadap queue jika kapasitas data tidak berbanding lurus dengan kapasitas line router untuk melewatkannya. Active queue management memiliki beberapa algoritma untuk mengontrol kongesti pada link jaringan antara lain DropTail, DRR (Deficit Round-Robin), dan RED (Random Early Detection).

Penelitian ini menganalisa performa teknologi algoritma congestion control berbasis active queue management dengan algoritma DropTail, DRR (Deficit Round-Robin), dan RED (Random Early Detection), pada jaringan backbone multicast berbasis PIM-DM (Protocol Independent Multicast-Dense Mode), yang disimulasikan dengan menggunakan network simulator 2 (NS2), untuk mendapatkan gambaran algoritma yang paling cocok di implementasikan pada jaringan multicast berbasis protocol multicast PIM-DM.

\subsection{Tujuan}

Tujuan yang ingin di capai dalam penelitian ini adalah :

1. Merancang dan membangun skenario jaringan backbone multicast berbasis Protocol Independent Multicast - Dense Mode (PIM-DM) yang terimplementasi konsep queue management dengan algoritma Deficit Round Robin (DRR), Droptail, dan Random Early Detection (RED).

2. Menganalisis performasi algoritma queue management tersebut dalam tiap skenario yang berbeda.

3. Mengetahui performa algoritma queue management yang dikelompokkan berdasarkan skenario yang di buat, dan pola pengukuran yang telah ditetapkan yaitu analisis delay, packet 
loss, dan throughput secara end to end serta analisis queue size, throughput, data lost pada tiap link jaringan backbone.

\subsection{Rumusan Masalah}

Berdasarkan permasalahan yang terdapat dalam latar belakang maka rumusan masalah dalam penelitian ini ditekankan pada :

1. Bagaimana mengukur dan menganalisa tingkat efektifitas masing-masing algoritma antrian dalam tiap skenario yang meliputi delay, packet loss dan throughput secara end to end serta analisis queue size, throughput, data lost pada tiap link jaringan backbone?

2. Bagaimana performa jaringan backbone multicast berbasis Protocol Independent Multicast - Dense Multicast (PIM-DM) yang terimplementasi algoritma queue management Deficit Round Robin (DRR), Droptail dan Random Early Detection (RED) dalam menangani beban traffic dan keadaan jaringan yang bervariasi?

\subsection{Tahapan Penelitian}

Untuk mencapai tujuan yang diinginkan dari penulisan materi penelitian ini, maka penulis melakukan beberapa kegiatan antara lain :

1. Kajian Pustaka : Mengumpulkan referensi yang berkaitan dengan penilitian yang dilakukan.

2. Desain Sistem : Melakukan perancangan simulasi meliputi penentuan topologi dan model skenario pengujian yang digunakan.

3. Perancangan Skenario Simulasi : Penelitian ini nantinya akan dibagi dalam tiga skenario. Topologi yang digunakan adalah sebuah topologi jaringan backbone sederhana berbasis Protocol Independent Multicast Dense Multicast, untuk pembangkit traffic digunakan Constant Bit Rate (CBR) sebagai pembangkit traffic yang constant pada parameter interval dan besar paket yang sama, sedangkan untuk mendukung layanan live multimedia streaming pada setiap server multicast di gunakan UDP sebagai protocol transport.

4. Pengujian dan Analisa : Kualitas penerimaan user end to end dari server multicast ke group multicast 1,2, dan 3 akan dianalisa melalui beberapa parameter antara lain throughput, delay, dan packet loss. Selain itu untuk menganalisa kerja dari algoritma congestion control pada tiap link juga akan dilakukan pengukuran yang meliputi queue size, data lost, dan throughput.

\section{Landasan Teori}

Internet telah mengalami perkembangan konsep menjadi media komunikasi universal yang bukan hanya sekedar melayani komunikasi berbasis text saja namun juga dapat menangani komunikasi suara bahkan video streaming. Perkembangan internet yang cenderung memiliki pola yang tidak seimbang ini akan menjadi masalah serius bagi layanan yang memanfaatkan jaringan internet. Tentunya beberapa alternative yang dapat dilakukan antara lain melakukan management secara menyeluruh di setiap aspeknya guna memanfaatkan sumber daya yang telah ada secara maksimal agar mampu menunjang berbagai layanan yang memanfaatkan jaringan internet tersebut. 


\subsection{Arsitektur TCP/IP}

Pada dasarnya sistem komunikasi antar komputer dalam suatu jaringan memerlukan dukungan sebuah protocol yang bertugas untuk mengatur bagaimana komunikasi antar komputer tersebut. TCP/IP suite (Transport Control Protocol / Internet Protocol) merupakan sekelompok protocol yang mengatur komunikasi data komputer dan memungkinkan komputer berbagai jenis, berbagai vendor, serta berbeda sistem operasi untuk berkomunikasi bersama dengan baik. Model protocol TCP/IP dapat digambarkan seperti pada gambar 1 .

\begin{tabular}{|c|}
\hline $\begin{array}{c}\text { Application Layer } \\
\text { Telnet, FTP, HTTP, etc }\end{array}$ \\
\hline $\begin{array}{c}\text { Tranport Layer } \\
\text { TCP, UDP }\end{array}$ \\
\hline $\begin{array}{c}\text { Internet Layer } \\
\text { IP, ICMP, IGMP }\end{array}$ \\
$\begin{array}{c}\text { Network Interface Layer } \\
\text { Device driver and interface card }\end{array}$ \\
\hline Jaringan Fisik \\
\hline
\end{tabular}

Gambar 1. Layer pada TCP/IP [4]

TCP (Transport Control Protocol) merupakan protocol yang berada pada layer transport dari layer TCP/IP. TCP adalah protocol yang bersifat byte stream, connection-oriented dan reliable dalam pengiriman data. TCP menggunakan komunikasi byte-stream, yang berarti bahwa data dinyatakan sebagai suatu urutan-urutan byte. Connection-oriented berarti sebelum terjadi proses pertukaran data antar komputer terlebih dahulu harus dibentuk suatu hubungan. Keandalan TCP dalam mengirimkan data didukung oleh mekanisme yang disebut Positive Acknowledgement wih Retransmission (PAR) [3].

UDP (User Datagram Protocol), merupakan protocol yang juga berada pada layer transport selain TCP. Protocol ini bersifat connectionless dan unreliable dalam pengiriman data. Connectionless berarti tidak diperlukannya suatu bentuk hubungan terlebih dahulu untuk mengirim data. Unreliable berarti pada protocol ini data tidak dijamin akan sampai pada tujuan yang benar dalam kondisi yang benar pula. Keandalan pengiriman data pada protocol ini menjadi tangung jawab dari program aplikasi pada layer diatasnya. Jika dibandingkan dengan TCP, UDP adalah protocol yang lebih sederhana dikarenakan proses yang ada di dalam lebih sedikit. Dengan demikian aplikasi yang memanfaatkan UDP sebagai protocol transport dapat mengirimkan data tanpa melalui proses pembentukan koneksi terlebih dahulu. Hal ini pun terjadi pada saat mengakhiri suatu koneksi, sehingga dalam banyak hal proses yang terjadi sangatlah sederhana dibanding jika mengirimkan data melalui protocol TCP. UDP bersifat broadcasting dan multicasting sehingga pengiriman datagram dengan menggunakan UDP ke banyak client sekaligus akan efisien jika prosesnya menggunakan connectionless [4]. Protocol UDP lebih sering diimplementasikan untuk aplikasi-aplikasi yang 
mengarah proses realtime seperti aplikasi multimedia, dimana rugi-rugi paket data yang kecil lebih ditoleransi daripada nilai delay yang terjadi.

\subsection{Protocol Independent Multicast (PIM)}

Protocol Independent Multicast (PIM) adalah merupakan kumpulan multicast routing protocol, dimana masing-masing dari tiap routing protocolnya dioptimalisasi untuk linkungan yang berbeda [3]. Setiap router yang mengimplementasikan PIM saling bertukar pesan untuk menentukan upstream interface dan downstream interface yang menghubungkan Source dengan Group (S, G ) sebagai satu kesatuan informasi. Ketika semua router di dalam jaringan telah menentukan upstream interface dan downstream interface yang menghubungkan Source dengan Group (S, G ), maka terbentuklah multicast tree, seperti terlihat pada gambar di bawah. Source dan router yang terhubung langsung dengan source sebagai akarnya, dan cabang-cabang yang merupakan semua subnet jaringan yang memiliki anggota setidaknya satu dari sebuah grup. Tidak ada cabang yang tidak memiliki anggota yang berhubungan dengan suatu grup. Mekanisme ini disebut juga reverse path multicast (RPM).. Dalam PIM terdapat dua jenis routing protocol yaitu PIM - Sparse Mode dan PIM - Dense Mode.

Protocol Independent Multicast - Sparse Mode (PIM - SM) adalah routing protocol multicast yang dirancang berdasarkan asumsi bahwa data tertentu yang dimulticast akan jarang di distribusikan ke seluruh jaringan. Dengan kata lain, diasumsikan bahwa kebanyakan subnet jaringan tidak ingin terhadap paket multicast tertentu. Untuk menerima data multicast router secara eksplisit harus memberitahukan tetangga hulu mereka tentang minat mereka dalam kelompok-kelompok tertentu dan sumber-sumber yang diinginkan. Router menggunakan PIM join dan prune message (pesan pemangkasan) untuk bergabung dan meninggalkan pohon distribusi multicast.

PIM-SM secara default menggunakan pohon bersama, dimana pohon distribusi multicast berakar pada beberapa node yang dipilih (Pada PIM router ini disebut Rendevous Point atau RP) dan digunakan oleh semua sumber untuk mengirimkan data ke group multicast. Untuk mengirim ke RP, sumber harus merangkum data dalam PIM control Message dan dikirim melalui unicast ke RP. Hal ini dilakukan oleh sumber Designated Router (DR), yang merupakan router pada jaringan lokal sumber. Sebuah DR tunggal dipilih dari semua router PIM pada jaringan, sehingga pesan kontrol yang tidak perlu tidak dikirim. Salah satu persyaratan penting dari PIM - Sparse Mode adalah kemampuan untuk menemukan alamat dari RP untuk grup multicast menggunakan pohon bersama. Dalam hal ini bebagai mekanisme untuk menemukan RP digunakan, termasuk konfigurasi statis, Bootstrap Router, Auto-RP, Anycast-RP, dan Embadded RP. PIM - SM juga mendukung penggunaan pohon berbasis source-based, dimana pohon distribusi multicast dibangun terpisah untuk masing-masing sumber pengirim data ke group multicast. Setiap pohon berakar pada router yang berdampingan dengan sumber, dan sumber langsung mengirim data ke akar pohon. Pohon yang berbasis source-based memungkinkan penggunaan Source-Specific Multicast (SSM), yang memungkinkan host untuk menentukan sumber dari mana mereka ingin menerima data, serta kelompok yang mereka ingin bergabung. Dengan SSM host mengidentifikasi aliran data multicast dengan pasangan alamat sumber dan grup (S, G), dari pada melalui alamat group saja (*, G). PIM SM adalah merupakan protocol soft-state, Yang setiap statenya akan time out beberapa saat setelah menerima control message. Untuk menjaga state- nya tetap hidup, pesan PIM join akan secara periodik dipancarkan kembali. 
Protocol Independent Multicast - Dense Mode (PIM - DM) adalah multicast Routing protocol yang dirancang berdasarkan asumsi yang berlawanan dengan PIM - SM yaitu setiap subnet dalam jaringan menginginkan data yang dimulticast, sehingga data yang dimulticast didistribusikan secara "padat" ke seluruh jaringan. Data multicast awalnya dikirim ke semua host di jaringan. Router yang tidak memiliki host yang tertarik terhadap data yang dimulticast akan mengirimkan PIM Prune message (Pesan pemangkasan) untuk melepaskan dirinya dari pohon distribusi multicast. Ketika sumber pertama kali mulai mengirimkan data, setiap router yang menerima data yang dimulticast akan meneruskan data tersebut ke semua router tetangga, setiap router yang menerima data yang diteruskan dari router tetangganya juga akan melakukan hal yang serupa, tapi hanya setelah memeriksa bahwa paket tiba pada upstream interface, jika tidak maka paket akan di drop. Mekanisme seperti ini mencegah terjadinya loop forwarding. Dengan cara ini berarti data membanjiri setiap bagian jaringan. Beberapa router yang tidak membutuhkan data akan merespon dengan mengirimkan PIM Prune message ke router tetangga hulu, yang akan menyebabkan router hulu berhenti menirimkan data ke tetangga hilir. Hal ini akan menyebabkan router hulu menjadi tidak memiliki kebutuhan atas data yang dimulticast maka router hulu akan kembali mengirimkan PIM Prune message ke tetangga hulunya dan begitu seterusnya. Prilaku 'broadcast dan Prune' ini berarti bahwa pada akhirnya data hanya akan dikirim pada bagian-bagian jaringan yang menbutuhkannya. Akhirnya prune state pada tiap router akan time out dan data akan mengalir kembali pada bagian yang sebelumnya dipangkas. Hal ini akan kembali memicu secara lebih lanjut pengiriman prune message, dan pada waktu tertentu prune state pada tiap router akan kembali time out. PIM-DM hanya menggunakan metode distribusi sumber berbasis pohon. Maka PIM-DM tidak menggunakan RP (Rendevous Point), yang membuatnya lebih sederhana dari PIM-SM. PIM-DM adalah merupakan protocol yang paling efisien ketika sebagian besar receiver tertarik terhadap data yang dimulticast.

\subsection{Teknologi Streaming}

Streaming adalah suatu teknologi untuk memainkan file audio atau video secara langsung maupun dengan prerecord dari sebuah mesin server (web server)[3]. File audio atau video yang terletak pada sebuah server dapat secara langsung dijalankan pada komputer client sesaat setelah ada permintaan dari pengguna sehingga proses download file tersebut yang menghabiskan waktu cukup lama dapat dihindari. Saat file tersebut di-stream maka akan terbentuk sebuah buffer di komputer client dan data audio atau video tersebut akan mulai di download ke dalam buffer yang telah terbentuk pada mesin client. Setelah buffer terisi dalam waktu hitungan detik, maka secara otomatis file video ataupun audio akan dijalankan oleh sistem. Sistem akan membaca informasi dari buffer sambil tetap melakukan proses download file sehingga proses streaming tetap berlangsung ke mesin client. Konsep dasar dari video streaming adalah membagi paket video ke dalam beberapa bagian, mentransmisikan paket tersebut, kemudian pada pihak penerima (client) dapat men-decode dan memainkan potongan paket file video tanpa harus menunggu seluruh file terkirim ke mesin penerima. Ada tiga tipe video streaming yaitu :

1. Video-on-Demand (VOD) adalah suatu bentuk streaming pada permintaan data yang sudah ada atau tersimpan dalam server. VOD membolehkan pengguna untuk dapat melakukan proses pause, rewind, fast forward, atau melakukan indeks isi multimedia.

2. Live Streaming, aplikasi live streaming dapat dijumpai pada teknologi broadcast radio dan televisi, aplikasi ini mengijinkan pengguna untuk menerima siaran radio dan televisi secara 
langsung (live). Dalam live streaming tidak ada data video yang disimpan di dalam server sehingga klien tidak dapat melakukan proses fast forward dalam media yang diakses. Proses capture dan encoding scara langsung dilakukan sesuai dengan format videonya sebelum video itu ditransmisikan kepada client.

3. Real-time Streaming, aplikasi ini mengijinkan pengguna untuk berkomunikasi dengan audio atau video dalam waktu yang riil. Contohnya adalah komunikasi tatap muka langsung melalui internet atau sering disebut dengan komunikasi video conference.

Protocol streaming bertujuan sebagai standardisasi komunikasi antara streaming server dan komputer klien [5]. Spesifikasi protokol streaming dibedakan menurut fungsinya yaitu:

1. Real-time Streaming Protocol (RTSP) RTSP adalah protokol level aplikasi yang berfungsi sebagai mekanisme kontrol pengiriman data audio atau video secara real-time. Protokol ini mempermudah klien ketika ingin melakukan proses pause atau mencari posisi random ketika memutar kembali data. Dengan kata lain, RTSP berlaku sebagai "network remote control". RTSP memiliki empat buah perintah. Perintah ini dikirim dari klien kepada server streaming. Keempat perintah tersebut adalah:

- Setup, server mengalokasikan sumber daya kepada klien.

- Play, server mengirim sebuah stream ke sesi klien yang telah dibangun dari perintah setup sebelumnya.

- Pause, server menunda pengiriman stream namun tetap menjaga sumber daya yang telah dialokasikan.

- Teardown, server memutuskan koneksi dan membebastugaskan sumber daya yang sebelumnya telah digunakan.

2. Empat perintah RTSP dapat dilakukan setelah klien dan server sudah berada dalam session yang disepakati. Klien melakukan proses DESCRIBE dan server merespon dengan protokol SDP (Session Description Protocol). Real-time Transport Protocol (RTP) Protokol yang didesain untuk memberikan layanan pengiriman end-to-end untuk data dengan karakteristik real-time seperti interaktif audio dan video secara unicast atau multicast dalam sebuah jaringan komputer (RFC-3550 2003). Protokol RTP berjalan di atas protokol UDP sebagai media transport. RTP didesain untuk digunakan pada tansport layer, namun demikian RTP digunakan diatas UDP, bukan pada TCP karena TCP tidak dapat beradaptasi pada pengiriman data yang real-time dengan keterlambatan yang relatif kecil seperti pada pengiriman data komunikasi suara. Dengan menggunakan UDP yang dapat mengirimkan paket IP secara multicast, RTP stream yang dibentuk oleh satu terminal dapat dikirimkan ke beberapa terminal tujuan. Selain itu, oleh karena informasi RTP dienkapsulasi dalam packet UDP. Jika packet RTP hilang (lost) atau didrop di jaringan, maka RTP tidak akan melakukan retransmission (sesuai standar protocol UDP). Hal ini dilakukan agar user tidak terlalu lama menunggu (long pause) atau delay, dikarenakan permintaan retransmission. 


\subsection{Active Queue Management (AQM)}

Kongesti dapat didefinisikan lebih tepat sebagai berikut: Suatu jaringan dikatakan congesti dari perspektif pengguna jika karena kenaikan beban jaringan, kualitas layanan yang dirasakan oleh pengguna kurang dari batas kualitas minimum yang masih dapat diterima oleh pengguna. Oleh karena hal tersebut peran utama algoritma Active queue management adalah menjaga titik fairness untuk paket data yang direquest untuk setiap client dalam jaringan serta memaksimalkan penggunaan sumber daya jaringan untuk menjaga Quality of Service dari tiap layanan, hingga pada titik tertentu dimana kondisi jaringan memang sudah tidak layak digunakan untuk layanan tertentu. Router sebagai pengatur lalu lintas paket data, memiliki sesuatu system antrian yang memungkinkan paket data yang masuk ke router disimpan terlebih dahulu sebelum diproses. Dengan adanya system antrian ini, paket-paket data yang masuk tidak serta merta ditolak oleh router ketika router ketika router sedang memproses suatu paket, tetapi menyimpannya terlebih dahulu pada suatu buffer. Buffer ini besarnya terbatas yang berakibat pada terbatasnya jumlah paket data yang dapat diantrikan pada router. Apabila buffer telah penuh maka paket data yang tiba selanjutnya akan ditolak sampai buffer cukup untuk menampungnya. Oleh karena itu dibuat suatu mekanisme pengaturan antrian agar jumlah paket data yang terbuang dapat diminimalisir. Mekanisme ini disebut Active Queue Management (AQM) [6].

Terdapat beberapa algoritma AQM yang ada dan sudah diimplementasikan pada jaringan komputer. Salah satu yang popular adalah RED. Selain itu terdapat pula algoritma lain seperti DRR dan Droptail. Namun. Semua algoritma tersebut tidak dapat berdiri sendiri untuk melakukan pengendalian congesti. Algoritma tersebut perlu didukung pengiriman paket data pada sisi pengirim, karena pada dasarnya AQM hanya menghasilkan keluaran berupa drop probability dan congestion price yang menginformasikan kondisi antrian di router. Dengan kata lain AQM memberikan keluaran pasif yang harus diproses secara aktif oleh host pengirim.

\subsubsection{Droptail}

Teknik antrian FIFO mengacu pada FCFS (First Come First Serve), paket data yang pertama datang diproses terlebih dahulu. Paket data yang keluar terlebih dahulu dimasukkan ke dalam antrian FIFO jika traffic melebihi nilai kapasitas link router maka paket data akan dimasukkan ke antrian, paket data tidak mengalami pembuangan hanya tertunda beberapa saat [1]. Data yang ada dalam antrian akan dikeluarkan sesuai dengan siapa yang lebih dulu masuk ke dalam antrian. Dengan jenis antrian FIFO paket akan dilayani berdasarkan laju kedatangan. Apabila kapasitas buffer telah penuh maka paket yang dating akan di drop. Mekanisme pelayanan paket untuk FIFO tidak ada prioritas pelayanan paket yang bersifat non-preempetive. Dengan artian, paket yang dating akan dilayani sampai selesai dan tidak bias diinterrupt hingga pelayanan terhadap paket yang bersangkutan selesai, walaupun ada paket dengan prioritas yang lebih tinggi. Pelayanan yang bersifat non-preempetive menimbulkan rata-rata waktu tunggu yang lebih besar dan akan berdampak pada tingginya paket yang di drop. Untuk mengatasi ini maka kita dapat menyesuaikan batas maksimum antrian.

\subsubsection{Random Early Detection (RED)}

RED merupakan teknik Active Queue Management (AQM) yang digunakan untuk jaringan IP berskala besar yang akan diterapkan pada IP Next Generation Network. RED menggunakan suatu paket drop profile untuk mengontrol keagresifan proses pembuangan paket. Drop profile 
mendefinisikan suatu tingkat probabilitas dropping paket melalui tingkat antrian. Algoritma RED menggunakan rata-rata panjang antrian untuk menentukan kapan paket ditandai. RED akan melakukan dropping suatu paket yang datang dengan menghitung probabilitas dropping-nya secara dinamis berdasarkan nilai rata-rata antriannya [1]. Nilai antrian rata-ratanya adalah:

$$
\operatorname{avg}(t)=(1-a) * \operatorname{avg}(t-1)+a . q, \text { dengan } a=0.02
$$

- Jika antrian rata-rata < batas minimum (minthresh), avg < min th maka RED akan melewatkan paket yang datang ke bottleneck link (diantrikan).

- Jika antrian rata-rata berada diantara batas minimum (minthresh) dan batas maksimum (maxthresh), min_th $<$ avg $<$ max_th maka RED akan membuang paket yang datang ke bottleneck link berdasarkan probabilitas $\mathrm{P} a$

$$
\boldsymbol{P} a=\frac{\max p *\left(a v g-\min _{\_} t h\right)}{\left(\max _{-} t h-\min _{-} t h\right)}
$$

- Dengan $\max \boldsymbol{p}=0.1$ merupakan batas maksimum probabilitas dropping.

- Jika antrian rata-rata $>$ batas maksimum (minthresh), avg $>$ max_th, maka RED akan membuang paket yang datang ke bottleneck link.

Mekanisme manajemen queue RED digambarkan seperti pada gambar 2.

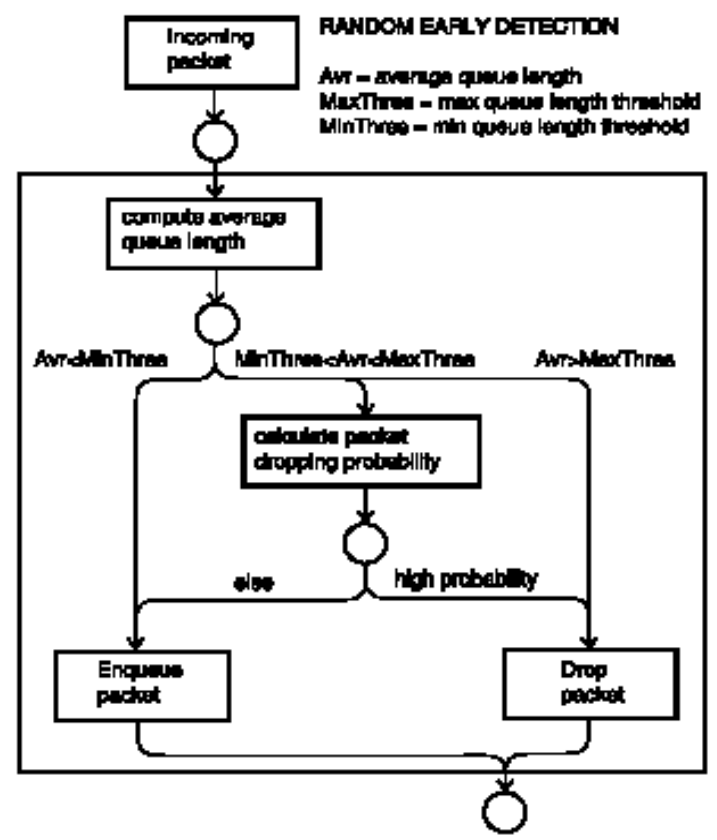

Gambar 2. Mekanisme management queue RED

\subsubsection{Deficit Round Robin (DRR)}

Deficit Round Robin (DRR) merupakan skema penjadwalan hasil dari modifikasi Weighted Round Robin (WRR), DRR membolehkan tiap kelas/prioritas memiliki panjang paket yang berbeda- 
beda sehingga tidak diperlukan lagi informasi mengenai ukuran paket rata-rata. Ide dasar DRR adalah suatu kelas berhak untuk mengirimkan paket dalam suatu putaran jika ukuran paket yang dimilikinya lebih kecil atau sama dengan ambang batas yang ditetapkan, ambang batas ini dinamakan Quantum yang merupakan padanan terhadap pembagian layanan untuk mendapatkan status Deficit Counter [6]. Mekanisme manajemen queue DRR digambarkan seperti pada gambar 3.

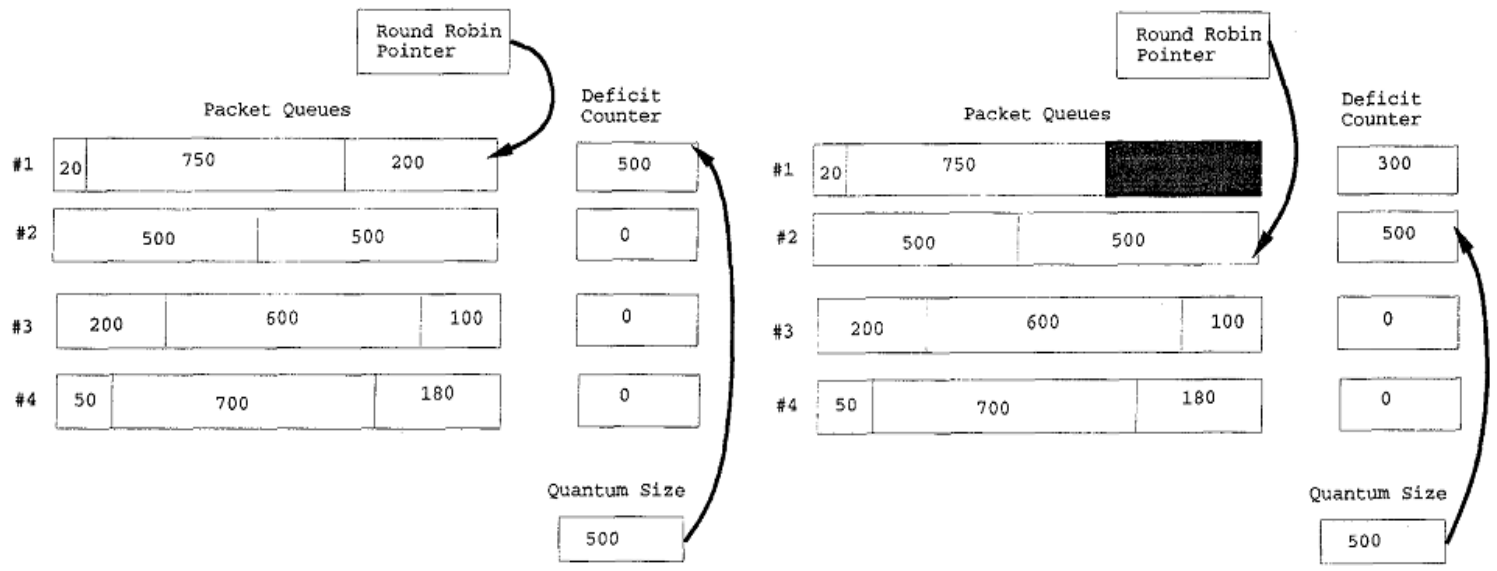

Gambar 3. Mekanisme management queue DRR [6]

Pada saat permulaan tiap putaran (round), Quantum ditambahkan ke Deficit Counter, kemudian jika paket Head-of-Line (HoL) di antrian tersebut berukuran lebih kecil atau sama dengan DeficitCounter, maka paket HoL tersebut akan dikirimkan dan Defict Counter akan berkurang, dikurangi oleh ukuran paket HoL, jika tidak maka paket $H o L$ tak akan dikirim pada putaran tersebut dan Deficit Counternya berukuran sama dengan nilai Quantum dimasing-masing antrian. Bila di dalam antrian tidak ada paket yang akan dikirimkan, Deficit Counter akan dikembalikan ke nilai 0. Nilai Quantum ditetapkan secara specific oleh algoritma berdasarkan lebar bandwidth pada tiap link jaringan.

\section{Perancangan Skenario Sistem}

Untuk melakukan pengujian performansi terhadap algoritma congestion control Droptail, DRR, dan RED dibuat masing-masing tiga buah skenario, dimana masing-masing scenario mencerminkan kondisi jaringan tertentu. Applikasi pembangkit traffic yang digunakan adalah Constant Bit Rate untuk membangkitkan traffic secara constant pada parameter interval. Video codec yang digunakan adalah standar H.264 dengan bit rate 1024 Kbps. Pada jaringan backbone terdapat enam buah server pembangkit background traffic dengan bit rate 3 Mbps. Masing-masing server multicast memiliki kapasitas pengiriman dan besar paket yang sama. pola pengukuran yang diterapkan yaitu analisa delay, packet loss, dan throughput secara end to end serta analisis queue size, throughput, data lost pada jalur multicast yang terbentuk.

\subsection{Perancangan Skenario 1}

Pada Skenario 1 client dari masing-masing group hanya ada satu, terdapat tiga group multicast, dan tiga server multicast. Masing-masing server multicast akan mengirimkan data secara simultan ke masing-masing group, server multicast 1 akan mengirimkan data secara multicast ke Provider 1 , begitu pula server multicast 2 akan mengirimkan data secara simultan ke Provider 2, dan server 
multicast 3 akan mengirimkan data ke Provider 3. Pada ruang lingkup internet backbone akan dibangkitkan beberapa jalur traffic background yang berbeda-beda.

Pembangkit traffic yang digunakan antara lain protocol CBR (Constant Bit Rate) berbasis TCP dan UDP, serta FTP yang berbasis TCP. Hal ini dimaksudkan untuk membuat ruang lingkup jaringan internet backbone dipenuhi dengan berbagai lalu lintas data (background traffic) dengan pola yang berbeda, sehingga akan tercermin konsep jaringan internet yang benar-benar sibuk, lalu akan dianalisa kualitas penerimaan user melalui aliran data dari server multicast ke masing-masing multicast group yang meliputi throughput, delay, dan packet lost. Selain itu untuk menganalisa kerja dari algoritma congestion control pada tiap link juga akan dilakukan pengukuran yang meliputi queue size, data lost, dan throughput.

Rancangan topologi untuk skenario 1 ditunjukkan pada gambar 4 dibawah ini :

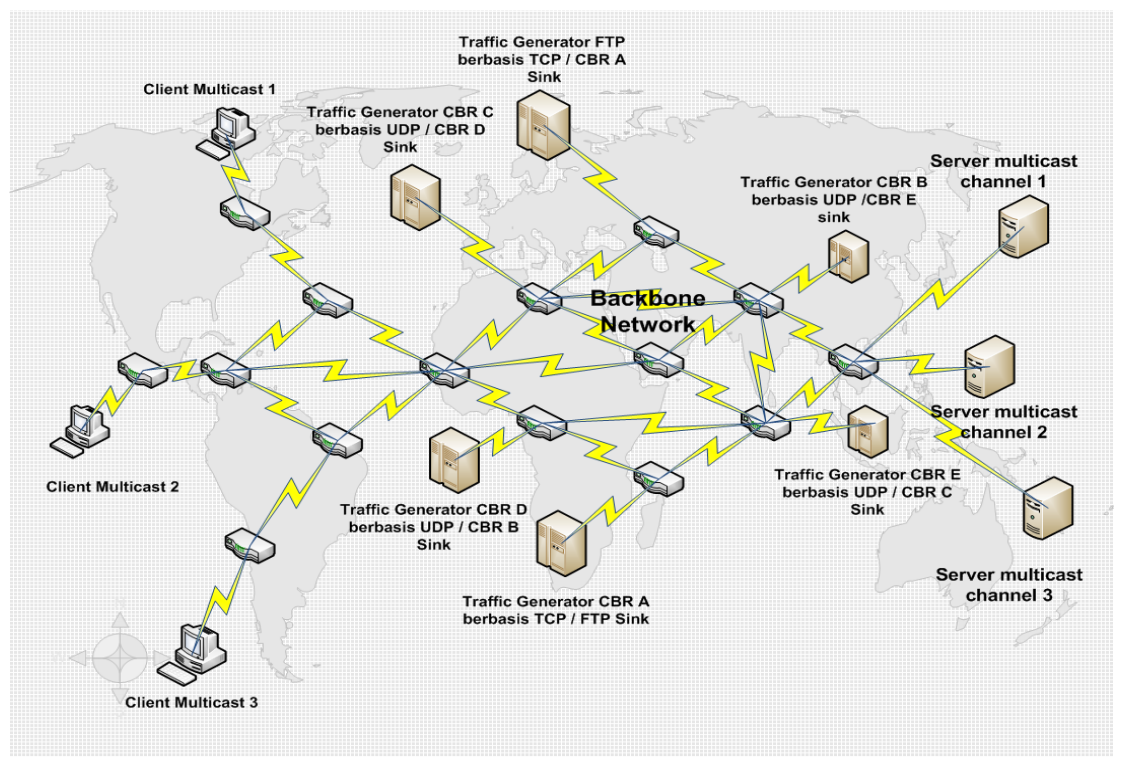

Gambar 4. Topologi jaringan skenario 1.

\subsection{Perancangan Skenario 2}

Pada skenario 2 dilakukan penambahan jumlah client pada group yang dianalisa sebelumnya yaitu dari satu buah client menjadi tiga buah client, serta penambahan tiga group lain (Provider 4, Provider 5, dan Provider 6) di titik tertentu yang berfungsi sebagai penambah beban multicast. Group baru yang ditambahkan memiliki client masing-masing empat buah. Aliran data dari server multicast 1 melayani kebutuhan data dari Provider 1 dan Provider 4, begitu pula server multicast 2 akan melayani kebutuhan data dari Provider 2 dan Provider 5, serta server multicast 3 akan melayani kebutuhan data dari Provider 3 dan Provider 6. Hal ini dimaksudkan untuk meninjau performa traffic management pada jaringan backbone multicast melalui penggunaan algoritma congestion control Deficit Round Robin (DRR), Random Early Detection (RED) dan DropTail dalam kondisi host yang lebih banyak. Kualitas penerimaan user end to end dari server multicast ke Provider 1, 2, dan 3 akan dianalisa melalui beberapa parameter antara lain throughput, delay, dan packet lost. Selain itu untuk menganalisa kerja dari algoritma congestion control pada tiap link juga akan dilakukan pengukuran yang meliputi queue size, data lost, dan throughput. 
Rancangan system yang diterapkan pada skenario 2 adalah seperti pada gambar 5 dibawah ini:

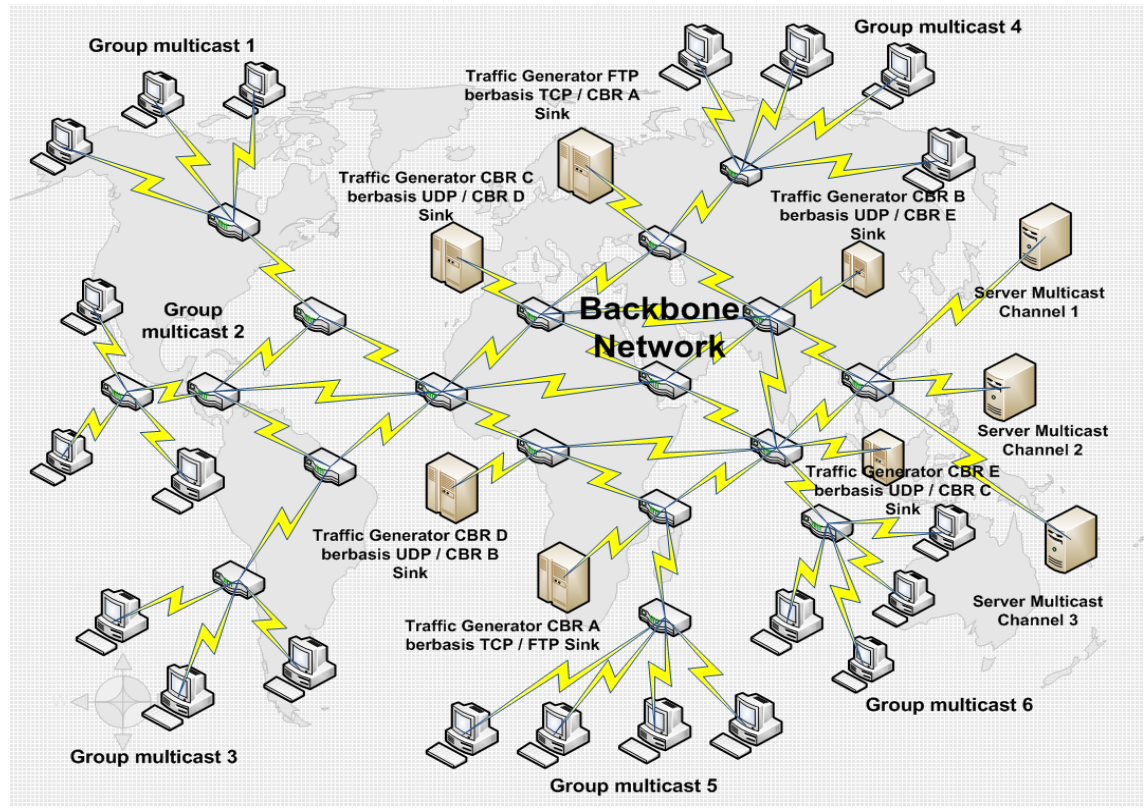

Gambar 5. Topologi jaringan skenario 2 .

\subsection{Perancangan Skenario 3}

Pada skenario 3 tetap pada konsep dan desain topologi yang sama dengan skenario 2 namun dengan aktifitas jaringan yang sedikit berbeda, dimana group multicast akan secara dinamis berpindah channel dalam kurun waktu tertentu, aturan yang digunakan seperti pada Tabel 1.

Tabel 1. Pola interkoneksi grup multicast terhadap server multicast.

\begin{tabular}{|l|l|l|l|l|}
\hline Waktu & Group Multicast & Server Multicast 1 & Server Multicast 2 & Server Multicast 3 \\
\hline \multirow{5}{*}{ Detik 5 } & Profider 1 & Connected & Disconnect & Disconnect \\
\cline { 2 - 5 } & Profider 2 & Disconnect & Connected & Disconnect \\
\cline { 2 - 5 } & Profider 3 & Disconnect & Disconnect & Connected \\
\cline { 2 - 5 } & Profider 4 & Connected & Disconnect & Disconnect \\
\cline { 2 - 5 } & Profider 5 & Disconnect & Connected & Disconnect \\
\cline { 2 - 5 } & Profider 6 & Disconnect & Disconnect & Connected \\
\hline \multirow{5}{*}{ Detik 15} & Profider 1 & Disconnect & Connected & Disconnect \\
\cline { 2 - 5 } & Profider 2 & Disconnect & Disconnect & Connected \\
\cline { 2 - 5 } & Profider 3 & Connected & Disconnect & Disconnect \\
\cline { 2 - 5 } & Profider 4 & Disconnect & Connected & Disconnect \\
\cline { 2 - 5 } & Profider 5 & Disconnect & Disconnect & Connected \\
\cline { 2 - 5 } & Profider 6 & Connected & Disconnect & Disconnect \\
\hline & Profider 1 & Disconnect & Disconnect & Connected \\
\cline { 2 - 5 } & Profider 2 & Connected & Disconnect & Disconnect \\
\cline { 2 - 5 } & Profider 3 & Disconnect & Connected & Disconnect \\
\cline { 2 - 5 } & Profider 4 & Disconnect & Disconnect & Connected \\
\cline { 2 - 5 } & Profider 5 & Connected & Disconnect & Disconnect \\
\cline { 2 - 5 } & Profider 6 & Disconnect & Connected & Disconnect \\
\hline
\end{tabular}


Pada scenario 3, aktifitas jaringan tidak hanya statis terhadap satu channel saja melainkan berpindah-pindah terhadap beberapa channel berbeda (Channel server multicast 1 , channel server multicast 2, dan channel server multicast 3 ) dalam kurun waktu tertentu. Hal ini dimaksudkan untuk meninjau performa traffic management pada jaringan backbone multicast melalui penggunaan algoritma congestion control Deficit Round Robin (DRR), Random Early Detection (RED), dan DropTail dalam kondisi host yang lebih padat serta request data yang dinamis dari tiga buah server multicast. Kualitas penerimaan user end to end dari server multicast ke group multicast 1, 2, dan 3 akan dianalisa melalui beberapa parameter antara lain throughput, delay, dan packet lost. Selain itu untuk menganalisa kerja dari algoritma congestion control pada tiap link juga akan dilakukan pengukuran yang meliputi queue size, data lost, dan throughput.

\section{Hasil dan Pembahasan}

\subsection{Analisis Performa Algoritma AQM pada Skenario 1}

Pada skenario 1 diuji bagaimana performansi dari masing-masing algoritma congestion control dalam menangani beban jaringan yang tidak begitu besar hanya satu buah member multicast untuk masing-masing server multicast. Traffic video dibangkitkan dengan menggunakan aplikasi traffic Constant Bit Rate (CBR), yang dikirimkan dari server multicast ke end user. masing-masing server multicast pada skenario 1 hanya akan memiliki satu member multicast. Video codec yang digunakan adalah standar H.264 dengan bit rate 1024 Kbps. Gambaran animasi topologi untuk scenario 1 ditampilkan pada gambar 6 .

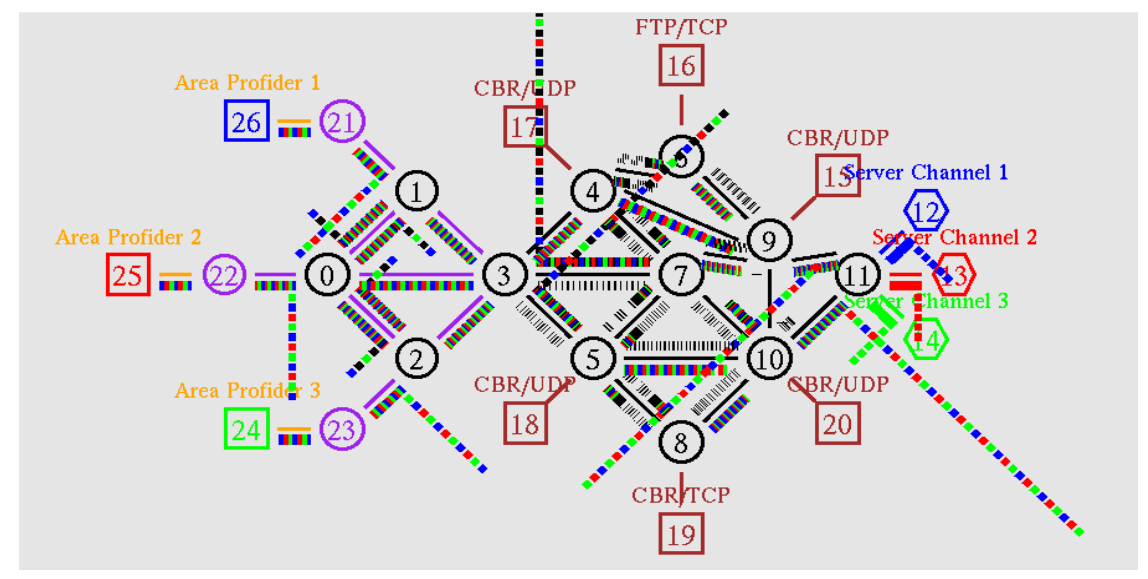

Gambar 6. Gambaran animasi topologi skenario 1.

\subsubsection{Analisa Delay dan Packet Loss}

Rata-rata delay yang diperoleh dari paket data yang dikirim oleh masing-masing server multicast dengan menggunakan algoritma congestion control DropTail, DRR, dan RED dapat dilihat pada gambar 7. 


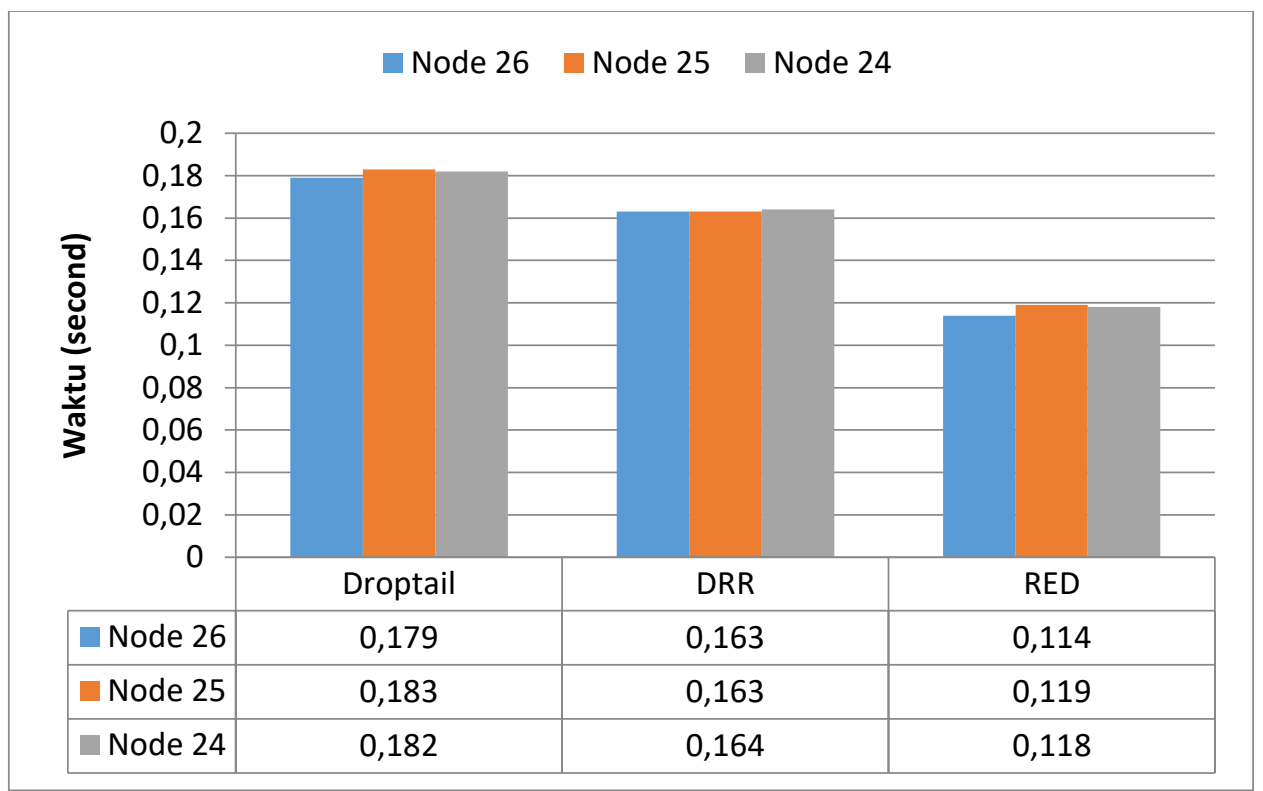

Gambar 7. Perbandingan rata-rata delay pada skenario 1.

Pada gambar 7 terlihat delay jaringan yang mengimplementasikan algoritma DRR memiliki catatan delay paling fair terhadap setiap beban traffic hal ini terlihat dari catatan mean delay jaringan yang mengimplementasikan DRR memiliki selisih mean delay paling kecil. Catatan mean delay DRR sekalipun tidak sebaik RED namun masih lebih baik dari pada droptail. Algoritma kendali kongesti RED terlihat memiliki kerja yang paling efisien untuk menekan delay pada setiap sesi pengiriman data, hal ini dikarenakan RED memiliki buffer size yang kecil sehingga paket data tidak akan berlama-lama berada dalam antrian. Sekalipun RED mampu menekan delay dengan sangat baik namun selisih mean delay RED terhadap setiap aliran data masih cukup besar jika dibandingkan dengan DRR yang memiliki tingkat fairness yang paling baik diantara ketiga algoritma congestion control yang diujikan.

Algoritma congestion control DRR memiliki mekanisme interupt yang lebih konsisten dan buffer size yang lebih besar dari pada RED sekalipun tidak lebih besar dari pada buffer size Droptail, sehingga DRR mampu mencatat nilai packet loss fairness yang paling baik dan mean loss yang lebih rendah dari RED. Perbandingan rata-rata packet loss pada skenario 1 ditampilkan pada gambar 8 .

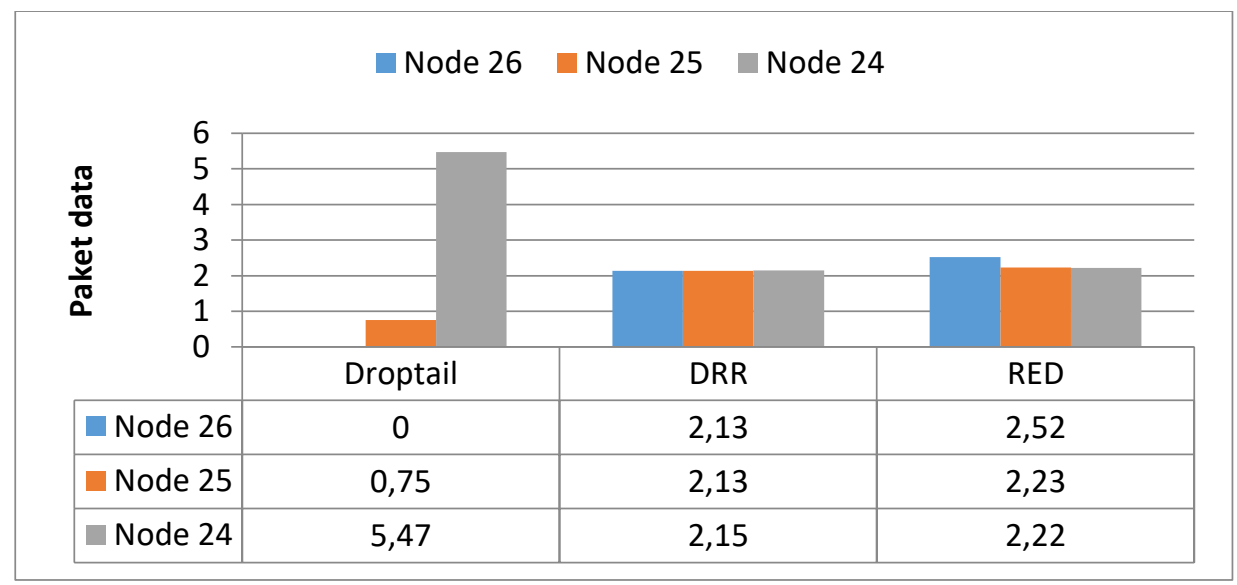

Gambar 8. Perbandingan rata-rata packet loss pada skenario 1. 


\subsubsection{Analisa Throughput}

RED dan DRR mampu menjaga nilai throughput lebih baik daripada Droptail terlihat dari nilai throughput yang didapat dalam jaringan yang menerapkan RED dan DRR sedikit lebih kecil dari pada catatan nilai mean throughput tertinggi Droptail untuk aliran data dari server multicast 1 , hal ini dikarenakan pada RED dan DRR dikenal system interupt terhadap paket data yang memiliki prioritas tertentu, sehingga pengalokasian bandwidth untuk tiap aliran data lebih adil. Perbandingan rata-rata throughput pada skenario 1 ditampilkan pada gambar 9.

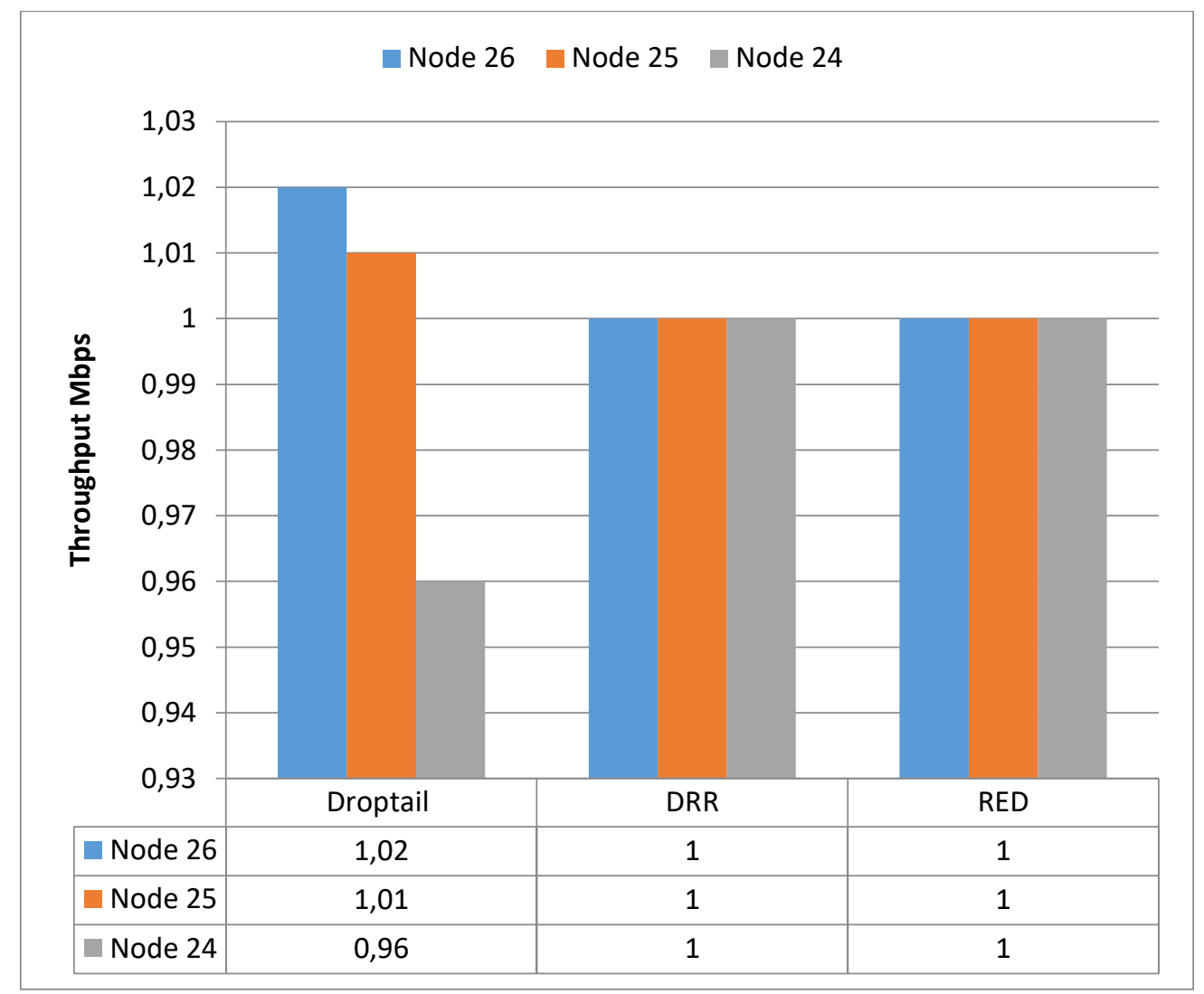

Gambar 9. Perbandingan rata-rata throughput pada skenario 1.

\subsubsection{Analisa Aktifitas Queue}

Catatan mean throughput pada gambar 10 menggambarkan bahwa router pada link 11-9, link 9-4, dan link 4-3 menggunakan kapasitas router secara keseluruhan pada setiap sesi, hal ini terlihat pada gambar 10, mean throughput mencatat angka 2,9 Mbps dari total kapasitas 3 Mbps.

RED memiliki nilai mean paket loss yang cukup tinggi bahkan dapat dikatan merupakan yang tertinggi diantara kompetitornya seperti ditampilkan pada gambar 11, hal ini dikarenakan buffer size RED lebih kecil dari pada Droptail dan DRR sehingga karena daya tampung yang kecil sementara arus data yang sangat cepat memang akan mengakibatkan buffer size RED akan lebih cepat overload ketimbang Droptail dan DRR. Pada gambar 12 terlihat bahwa kapasitas queue size RED jauh lebih kecil dibandingkan DRR dan Droptail, hal ini memang dikarekan buffer size RED yang tidak sebesar DRR dan droptail. 


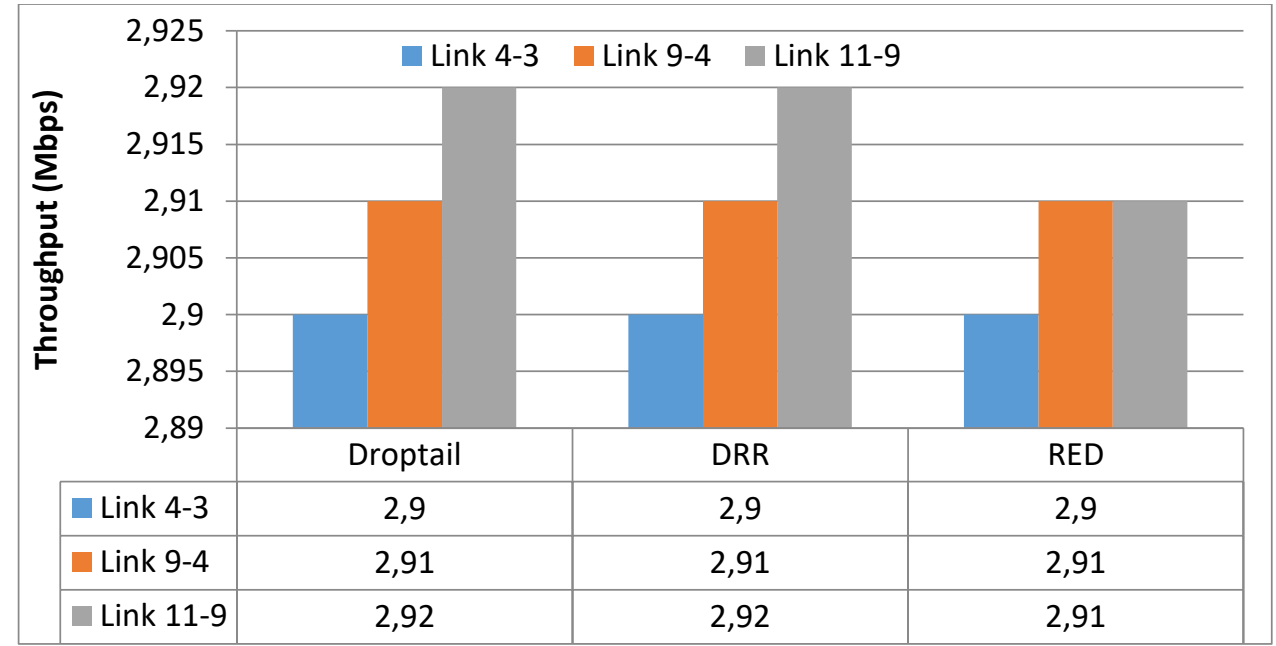

Gambar 10. Perbandingan rata-rata throughput jalur multicast pada skenario 1.

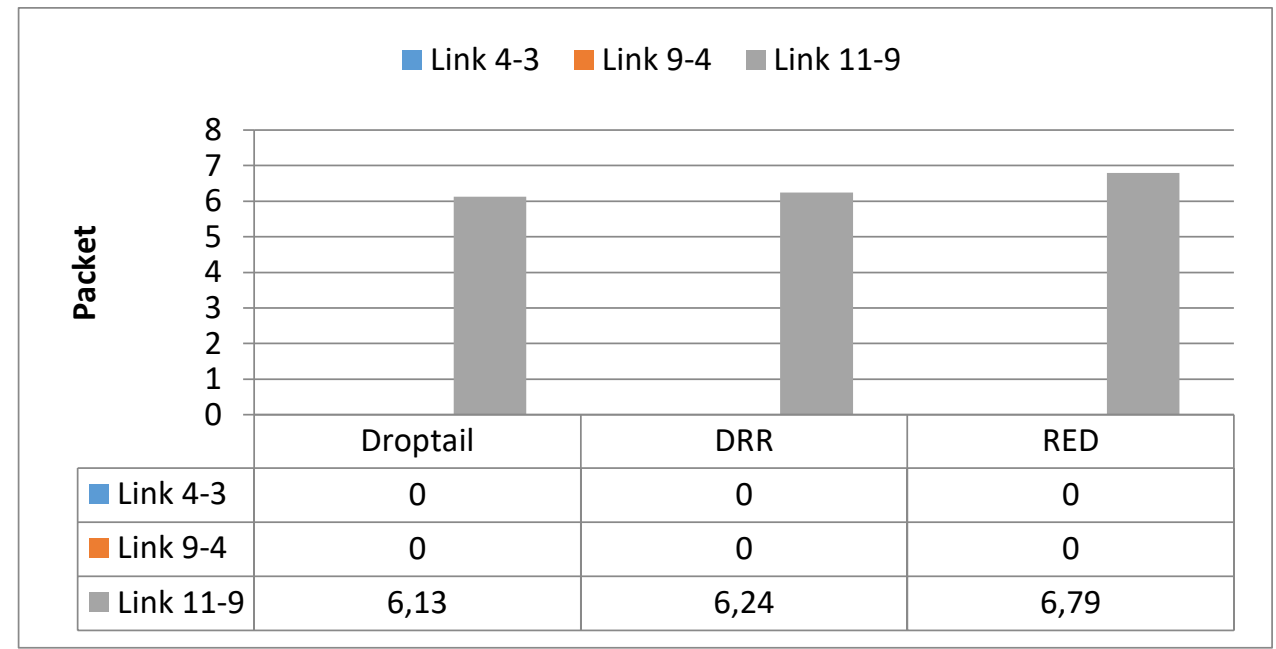

Gambar 11. Perbandingan rata-rata packet loss jalur multicast pada skenario 1.

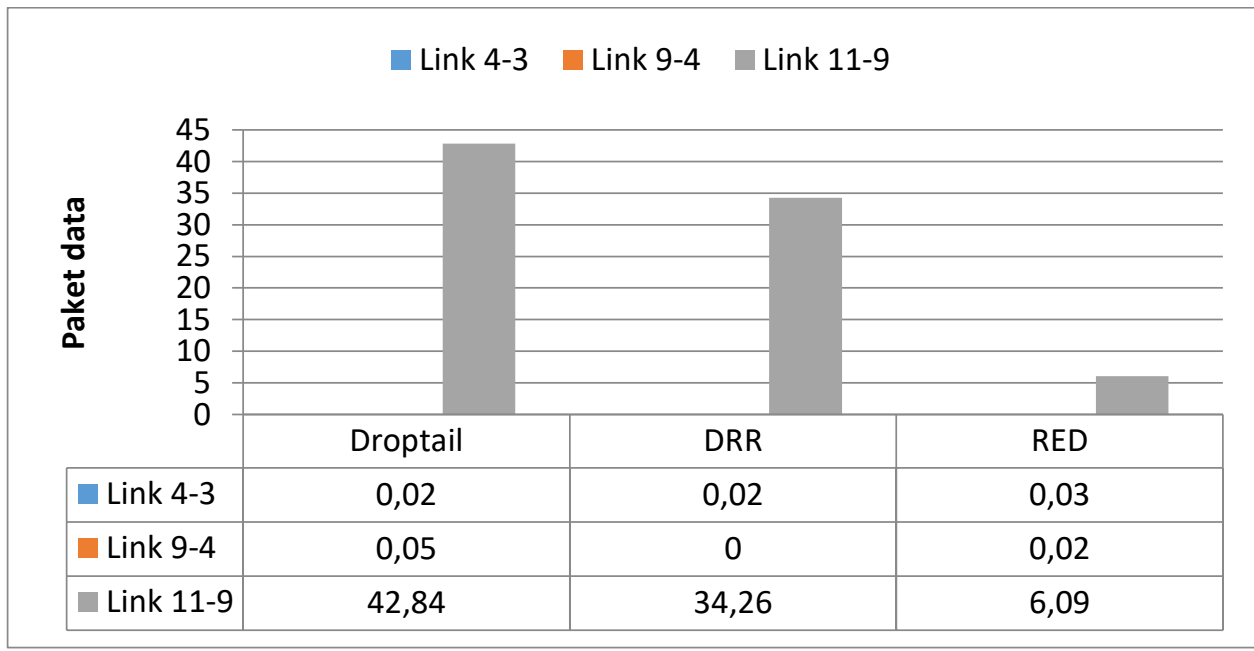

Gambar 12. Perbandingan rata-rata queue size jalur multicast pada skenario 1. 


\subsection{Analisis Performa Algoritma AQM pada Skenario 2}

Pada skenario 2 diuji bagaimana performansi dari masing-masing algoritma congestion control dalam menangani kuantitas beban jaringan yang besar, terdapat sembilan member multicast pada provider 1, 2, dan 3, selain itu juga terdapat penambahan 3 provider lain yang masing-masing memiliki member multicast empat buah node, provider tambahan ini difungsikan sebagai penambah beban multicast untuk server multicast. Gambaran animasi topologi untuk skenario 2 ditampilkan pada Gambar 13.

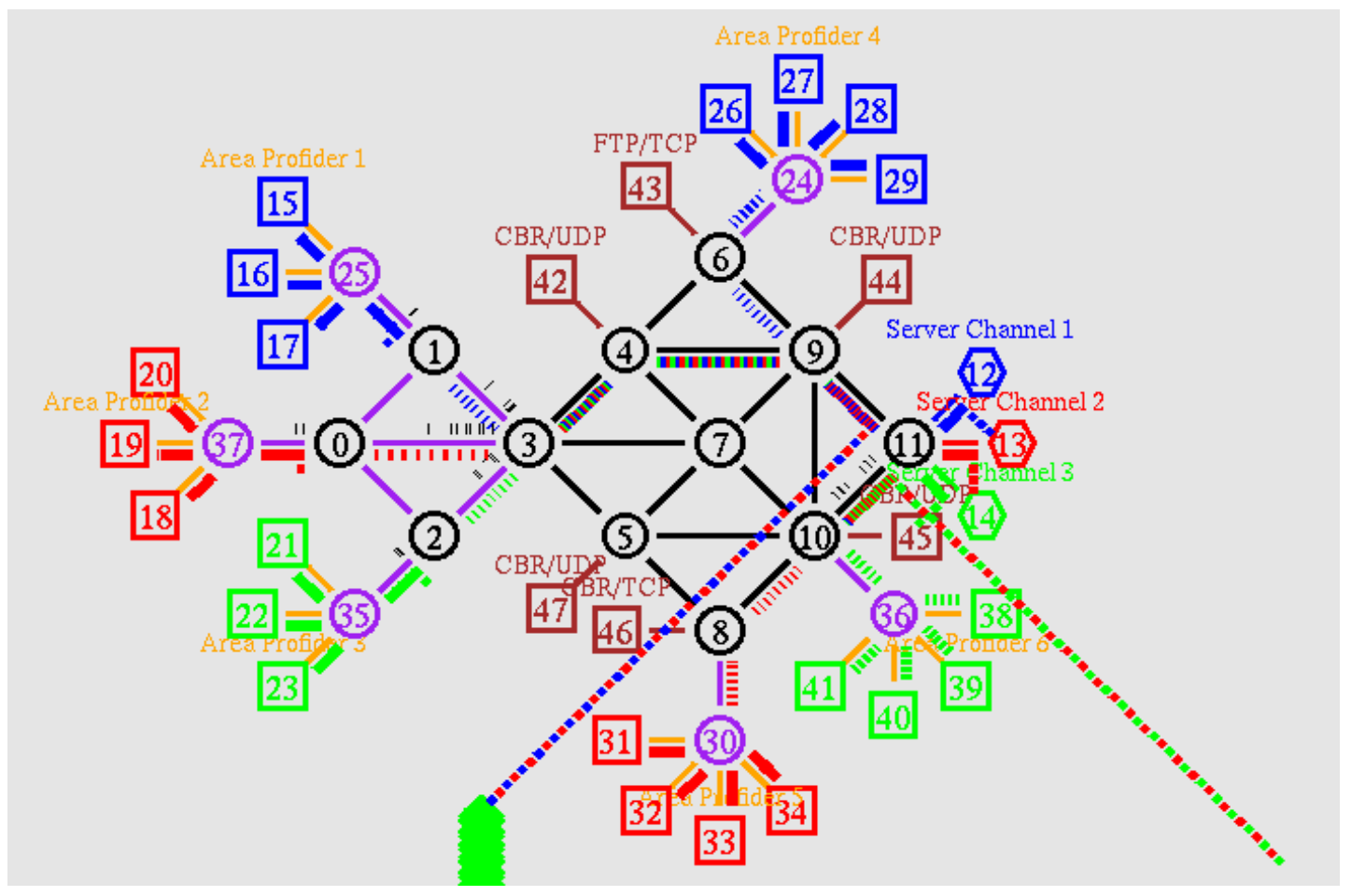

Gambar 13. Gambaran animasi topologi skenario 2.

\subsubsection{Analisa Delay dan Packet Loss}

Berdasarkan data pada Gambar 14, algoritma congestion control RED terlihat memiliki kerja yang paling efisien untuk menekan delay pada setiap sesi pengiriman data hal ini dikarenakan RED memiliki buffer size yang kecil. Berdasarkan data pada gambar Penambahan beban traffic pada skenario 2 tidak menambah nilai mean delay terhadap data yang di distribusikan, hal ini terlihat dari angka mean delay yang tercatat pada skenario 1 tidak mengalami peningkatan yang significan pada skenario 2. Gambar 15 menunjukkan algoritma congestion control DRR sekalipun memiliki nilai rata-rata mean loss lebih rendah dari pada Droptail, namun DRR memiliki loss fairness lebih baik daripada Droptail dan RED, dengan selisih mean loss paling kecil untuk setiap aliran datanya. 


\begin{tabular}{|c|c|c|c|c|c|}
\hline \multirow{7}{*}{ 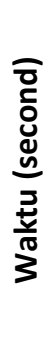 } & \multirow{7}{*}{$\begin{array}{r}0,2 \\
0,18 \\
0,16 \\
0,14 \\
0,12 \\
0,1 \\
0,08 \\
0,06 \\
0,04 \\
0,02 \\
0\end{array}$} & \multirow[b]{7}{*}{ Droptail } & \multirow[b]{7}{*}{ DRR } & \multirow[b]{7}{*}{ RED } & \multirow{7}{*}{$\begin{array}{l}\text { Node } 15 \\
\text { Node } 16 \\
\text { Node } 17\end{array}$} \\
\hline & & & & & \\
\hline & & & & & \\
\hline & & & & & \\
\hline & & & & & \\
\hline & & & & & \\
\hline & & & & & \\
\hline & lode 15 & 0,18 & 0,16 & 0,12 & \multirow{2}{*}{$\begin{array}{l}\text { Node } 18 \\
\text { Node } 19\end{array}$} \\
\hline \multicolumn{2}{|c|}{ Node 16} & 0,18 & 0,16 & 0,12 & \\
\hline \multicolumn{2}{|c|}{ Node 17} & 0,18 & 0,16 & 0,12 & Node 20 \\
\hline \multicolumn{2}{|c|}{ Node 18} & 0,18 & 0,16 & 0,12 & \multirow{3}{*}{$\begin{array}{l}\text { Node } 21 \\
\text { Node } 22 \\
\text { Node } 23\end{array}$} \\
\hline \multicolumn{2}{|c|}{ Node 19} & 0,18 & 0,16 & 0,12 & \\
\hline \multicolumn{2}{|c|}{ Node 20} & 0,18 & 0,16 & 0,12 & \\
\hline \multicolumn{2}{|c|}{$\square$ Node 21} & 0,18 & 0,16 & 0,12 & \\
\hline \multicolumn{2}{|c|}{ Node 22} & 0,18 & 0,16 & 0,12 & \\
\hline \multicolumn{2}{|c|}{ Node 23} & 0,18 & 0,16 & 0,12 & \\
\hline
\end{tabular}

Gambar 14. Perbandingan rata-rata delay pada skenario 2.

\begin{tabular}{|c|c|c|c|}
\hline \multirow{5}{*}{$\left.\begin{array}{l}6 \\
5 \\
4 \\
3 \\
2 \\
1 \\
0\end{array}\right]$} & \multicolumn{3}{|c|}{$\begin{array}{l}\text { Node } 15 \square \text { Node } 16 \square \text { Node } 17 \square \text { Node } 18 \square \text { Node } 19 \\
\text { Node } 20 \square \text { Node } 21 \square \text { Node } 22 \square \text { Node } 23\end{array}$} \\
\hline & \multirow{3}{*}{$\begin{array}{l} \\
\\
\\
\\
\end{array}$} & \multirow[b]{4}{*}{ DRR } & \multirow[b]{4}{*}{ RED } \\
\hline & & & \\
\hline & & & \\
\hline & Droptail & & \\
\hline Node 15 & 0 & 2,13 & 2,28 \\
\hline Node 16 & 0 & 2,13 & 2,28 \\
\hline Node 17 & 0 & 2,13 & 2,28 \\
\hline Node 18 & 0,65 & 2,13 & 2,35 \\
\hline Node 19 & 0,65 & 2,13 & 2,35 \\
\hline Node 20 & 0,65 & 2,13 & 2,35 \\
\hline Node 21 & 5,58 & 2,15 & 2,32 \\
\hline Node 22 & 5,58 & 2,15 & 2,32 \\
\hline Node 23 & 5,58 & 2,15 & 2,32 \\
\hline
\end{tabular}

Gambar 15. Perbandingan rata-rata packet loss pada skenario 2.

\subsubsection{Analisa Throughput}

Pada Gambar 16 terlihat DRR memiliki throughput yang sama untuk setiap aliran data yang berarti tingkat throughput fairness DRR pada skenario 2 lebih baik dari pada RED dan Droptail selain itu nilai rata-rata mean throughput DRR lebih besar daripada RED dan Droptail. RED dan 
DRR memiliki mekanisme penggunaan throughput yang seimbang karena pada kedua algoritma ini mengadopsi system interupt.

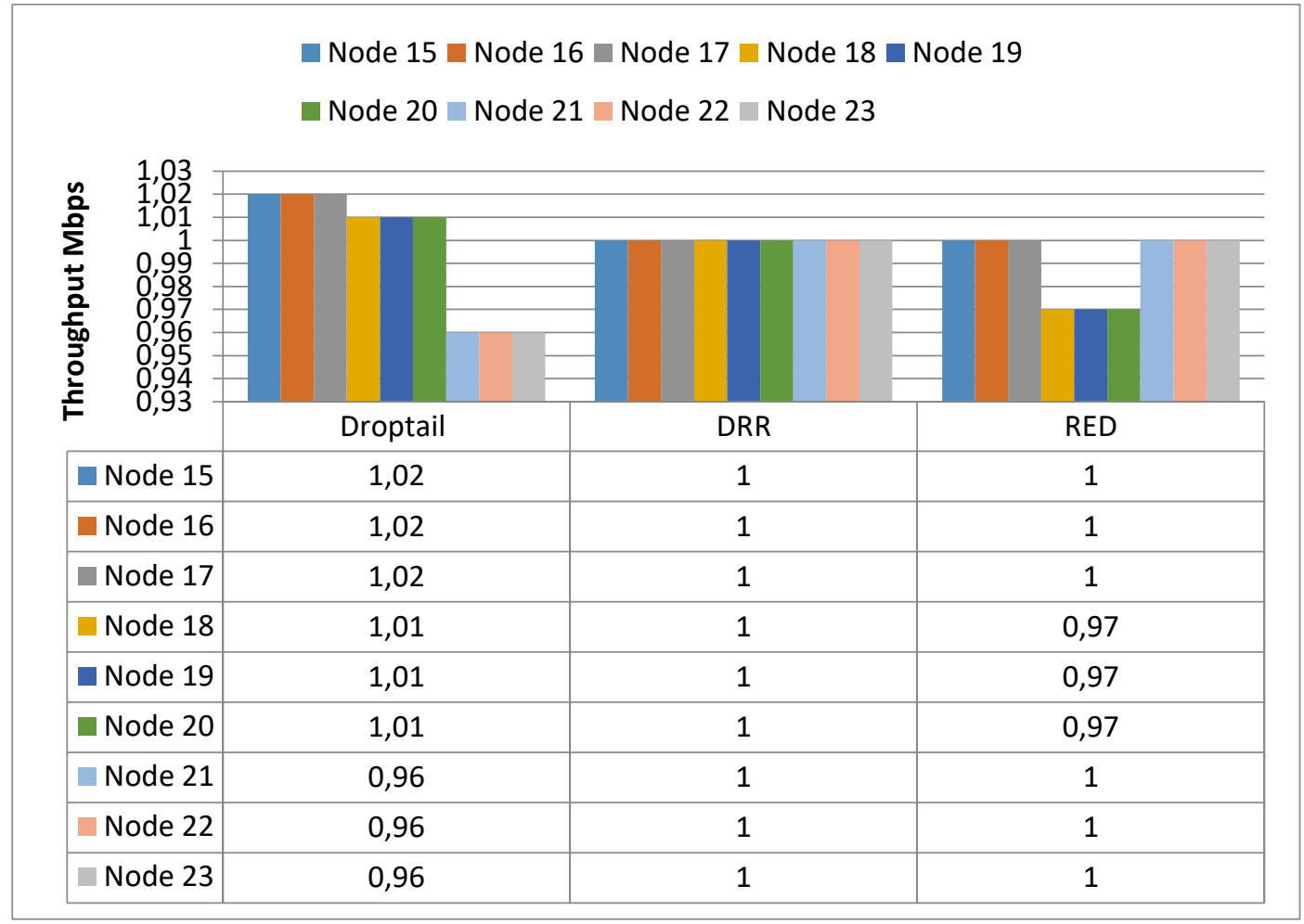

Gambar 16. Perbandingan rata-rata throughput pada skenario 2 .

\subsubsection{Analisa Aktifitas Queue}

Pada skenario 2 data yang tercatat pada Gambar 17 mengenai mean throughput masih serupa dengan skenario 1. Data mean loss pada skenario 2 seperti yang ditampilkan pada gambar 18 mengalami penurunan nilai mean loss jika dibandingkan dengan data mean loss skenario 1, penurunan terjadi pada jaringan berbasis Droptail dan RED masing-masing sebesar 0.02 paket.

Berdasarkan data pada gambar 19 dapat disimpulkan penambahan beban multicast pada skenario 2 menyebabkan terjadinya peningkatan nilai mean queue size pada pada jaringan berbasis Droptail, DRR, dan RED, hal ini dilihat dari membandingkan nilai mean queue size pada skenario 1 dan skenario 2.

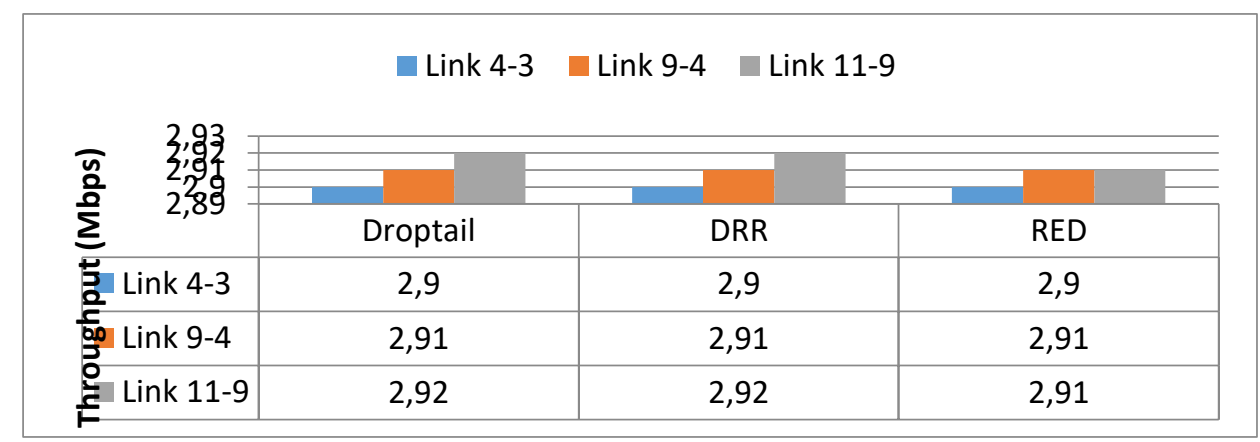

Gambar 17. Perbandingan rata-rata throughput jalur multicast pada skenario 2. 


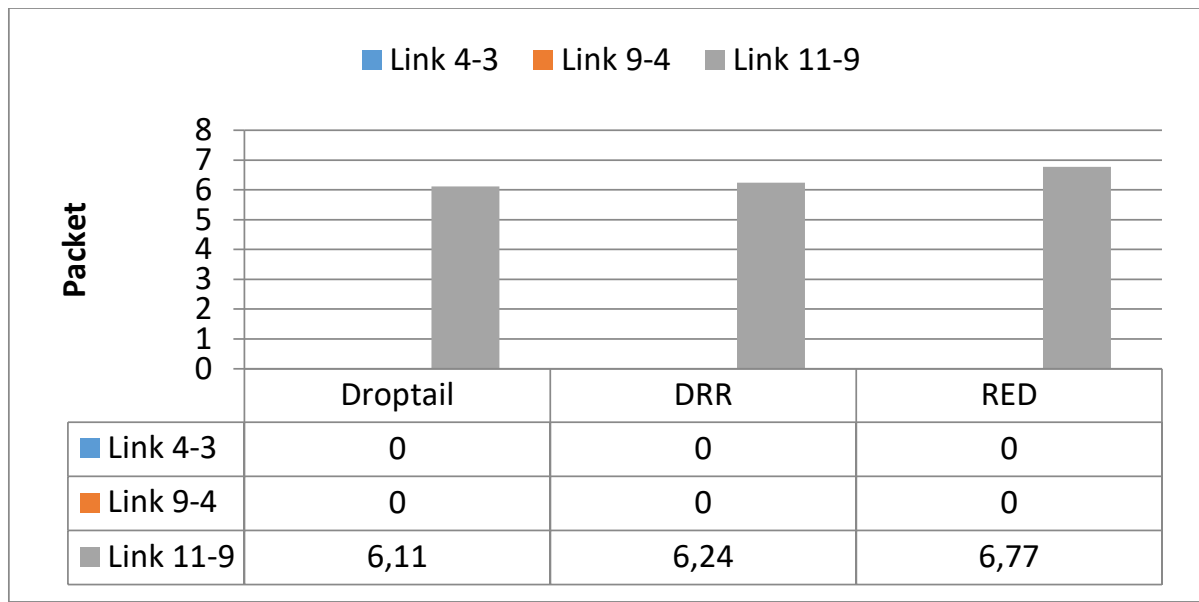

Gambar 18. Perbandingan rata-rata packet loss jalur multicast pada skenario 2.

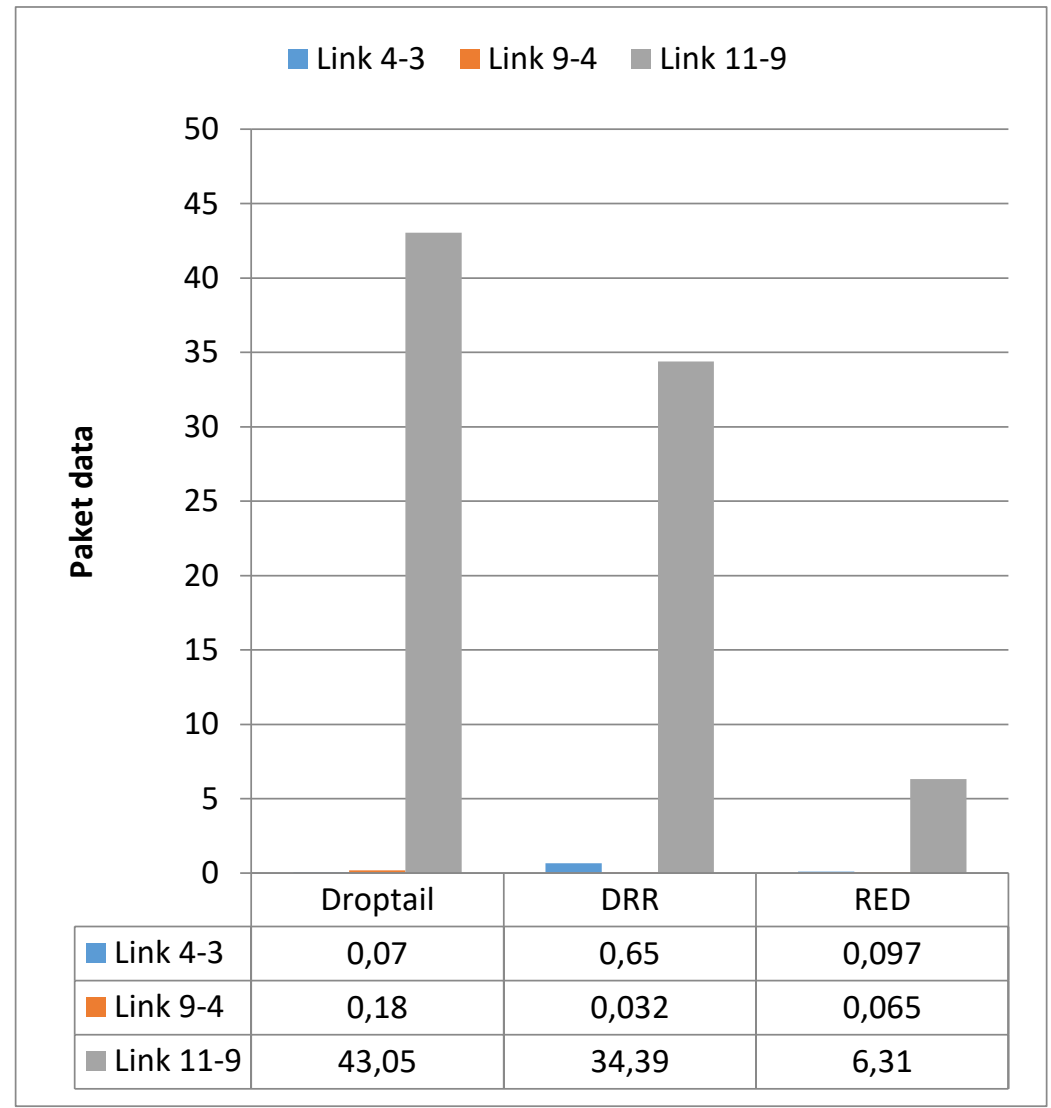

Gambar 19. Perbandingan rata-rata queue size jalur multicast pada skenario 2.

\subsection{Analisis Performa Algoritma AQM pada Skenario 3}

Pada skenario 3 diujikan bagaimana performansi dari masing-masing algoritma congestion control dalam menangani beban jaringan yang besar sekaligus bersifat dinamis. Konsep jaringan yang di terapkan pada skenario 3 masih serupa dengan konsep jaringan pada skenario 2 yang membedakan hanyalah aktifitas member multicast yang akan secara dinamis berpindah-pindah server multicast yang berbeda selama 10 detik waktu simulasi. Gambaran animasi topologi untuk skenario 3 ditampilkan pada Gambar 20. 


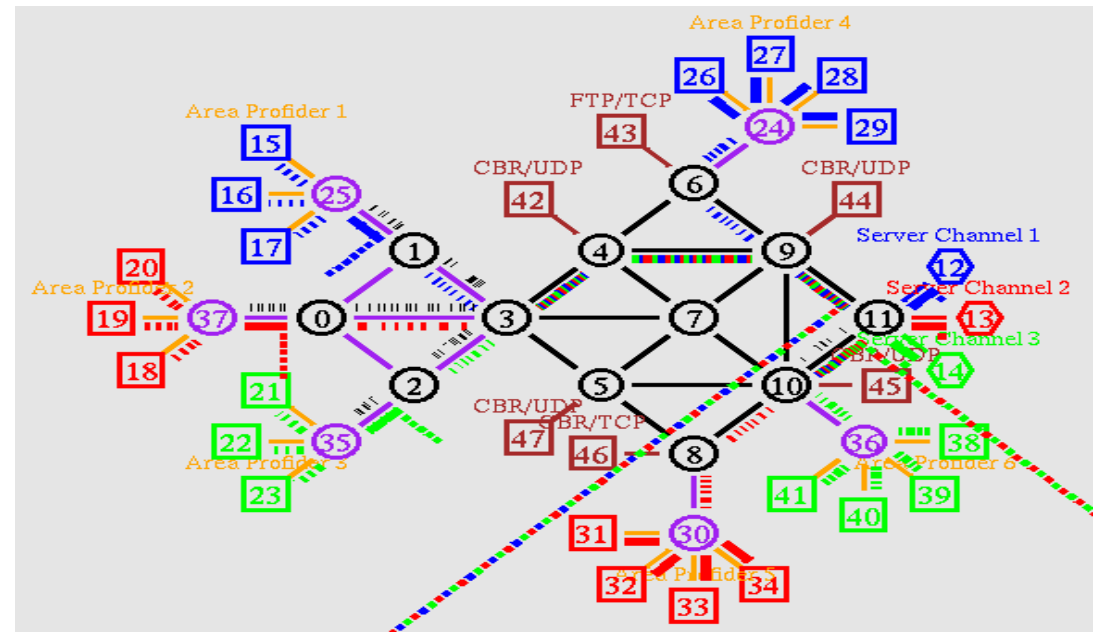

Gambar 20. Gambaran animasi topologi skenario 3.

\subsubsection{Analisa Delay dan Packet Loss}

Berdasarkan Gambar 21, 22, dan 23, secara keseluruhan masing-masing algoritma congestion control mencatat nilai delay fairness yang sangat baik, terlihat pada pencatatan mean delay nampak bahwa mean delay setiap aliran data memiliki nilai yang sama pada detik ke 5 hingga ke 15. Pada detik ke 15 hingga 25 terjadi peningkatan mean delay pada jaringan berbasis droptail, peningkatan terjadi pada aliran data dari server multicast 2 dan server multicast 3 sebesar 0.01 detik dari sesi sebelumnya (detik ke 5 hingga detik ke 15).

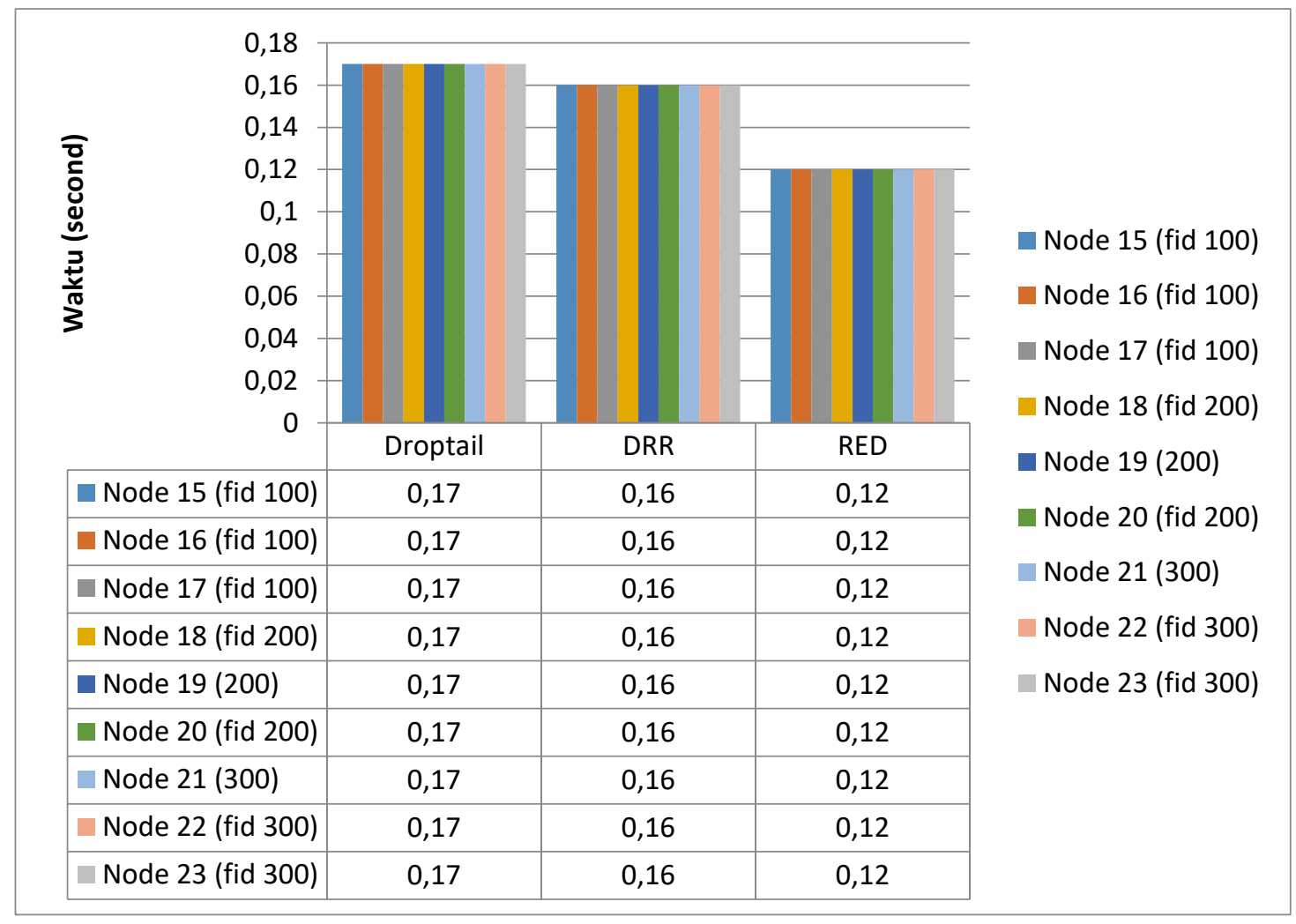

Gambar 21. Perbandingan rata-rata delay detik ke 5 hingga detik ke 15. 


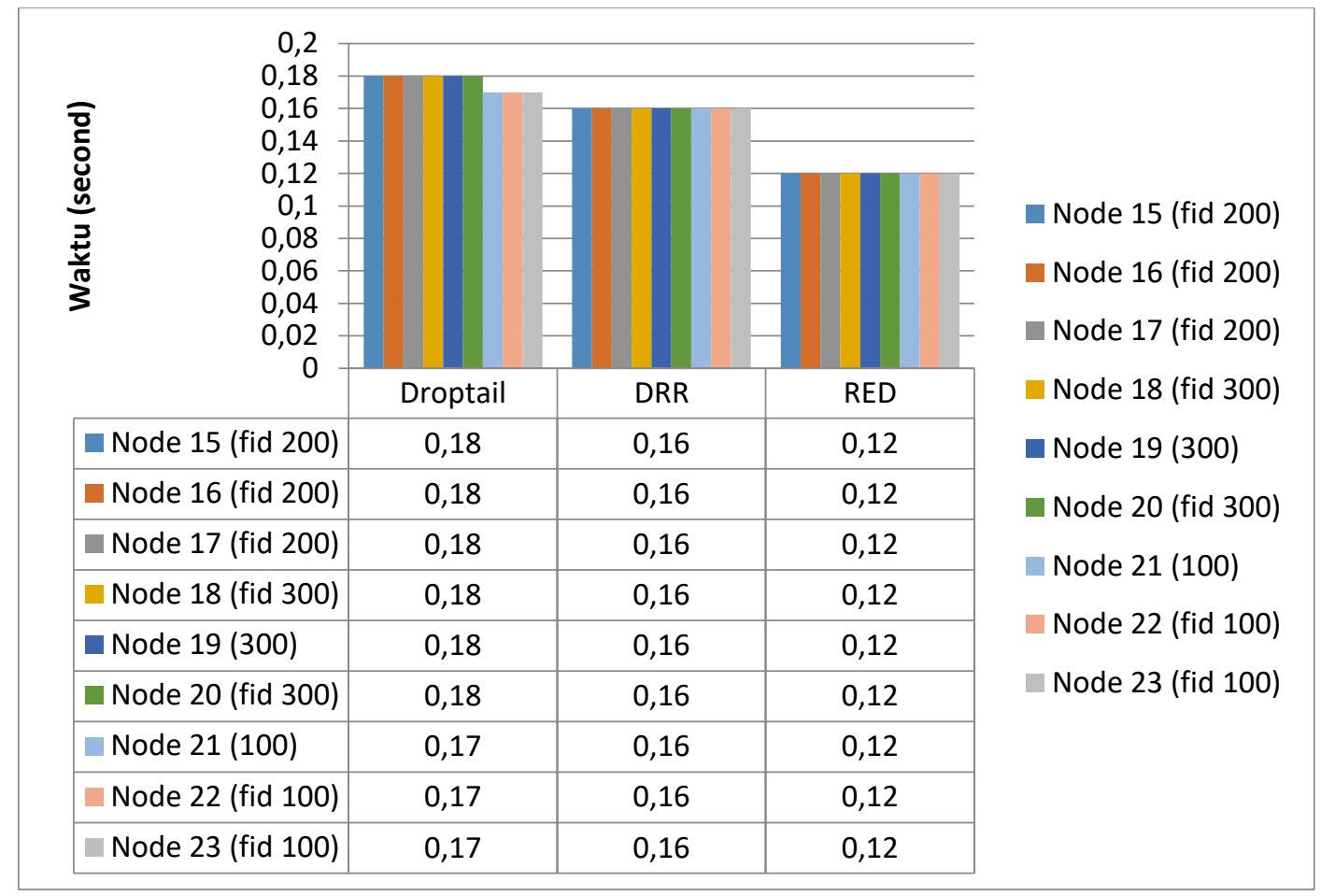

Gambar 22. Perbandingan rata-rata delay detik ke 15 hingga detik ke 25.

\begin{tabular}{|c|c|c|c|c|c|}
\hline \multirow{10}{*}{ 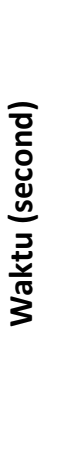 } & 0,2 & & & & \multirow{10}{*}{$\begin{array}{l}\text { Node } 15 \text { (fid 300) } \\
\text { Node } 16 \text { (fid 300) } \\
\text { Node } 17 \text { (fid 300) } \\
\text { Node } 18 \text { (fid 100) }\end{array}$} \\
\hline & 0,18 & & & & \\
\hline & 0,16 & & & & \\
\hline & 0,14 & & & & \\
\hline & 0,12 & & & & \\
\hline & 0,1 & & & & \\
\hline & 0,08 & & & & \\
\hline & 0,06 & & & & \\
\hline & \multirow{2}{*}{$\begin{array}{r}0,02 \\
0\end{array}$} & & & & \\
\hline & & Droptail & DRR & RED & \\
\hline & Node 15 (fid 300) & 0,19 & 0,17 & 0,12 & \multirow{9}{*}{$\begin{array}{l}\text { Node } 19 \text { (100) } \\
\text { Node } 20 \text { (fid 100) } \\
\text { Node } 21 \text { (200) } \\
\text { Node } 22 \text { (fid 200) } \\
\text { Node } 23 \text { (fid 200) }\end{array}$} \\
\hline & Node 16 (fid 300) & 0,19 & 0,17 & 0,12 & \\
\hline & Node 17 (fid 300) & 0,19 & 0,17 & 0,12 & \\
\hline & Node 18 (fid 100) & 0,18 & 0,17 & 0,11 & \\
\hline & Node 19 (100) & 0,18 & 0,17 & 0,11 & \\
\hline & Node 20 (fid 100) & 0,18 & 0,17 & 0,11 & \\
\hline & Node 21 (200) & 0,19 & 0,17 & 0,12 & \\
\hline & Node 22 (fid 200) & 0,19 & 0,17 & 0,12 & \\
\hline & Node 23 (fid 200) & 0,19 & 0,17 & 0,12 & \\
\hline
\end{tabular}

Gambar 23. Perbandingan rata-rata delay detik ke 25 hingga detik ke 35.

Pada detik ke 25 hingga detik ke 35 masing-masing algoritma congestion control mengalami penurunan nilai mean delay fairness. Terjadi peningkatan mean delay pada jaringan berbasis droptail 
dan DRR, peningkatan terjadi pada aliran data dari setiap server multicast, sebesar 0.01 second jika dibandingkan dengan sesi sebelumnya (detik 15 hingga detik 25).

\subsubsection{Analisa Throughput dan Packet Loss}

Perilaku member multicast yang dinamis sangat mempengaruhi nilai loss fairness dan peningkatan nilai rata-rata mean loss fairness yang cukup signifikan pada setiap algoritma congestion control, hal ini dibuktikan dengan nilai mean loss pada skenario 3 yang ditampilkan pada Gambar 24 jauh lebih besar jika dibandingkan nilai mean loss skenario 2. Pada skenario 3 terdapat penurunan nilai mean throughput seperti ditampilkan pada Gambar 25, dikarenakan terjadi perpindahan masing-masing member multicast terhadap server multicast sehingga untuk melakukan reconnection terhadap joint server terbaru PIM-DM memerlukan waktu hingga prune state time out, selisih waktu ini yang membuat penurunan nilai mean throughput menurun.

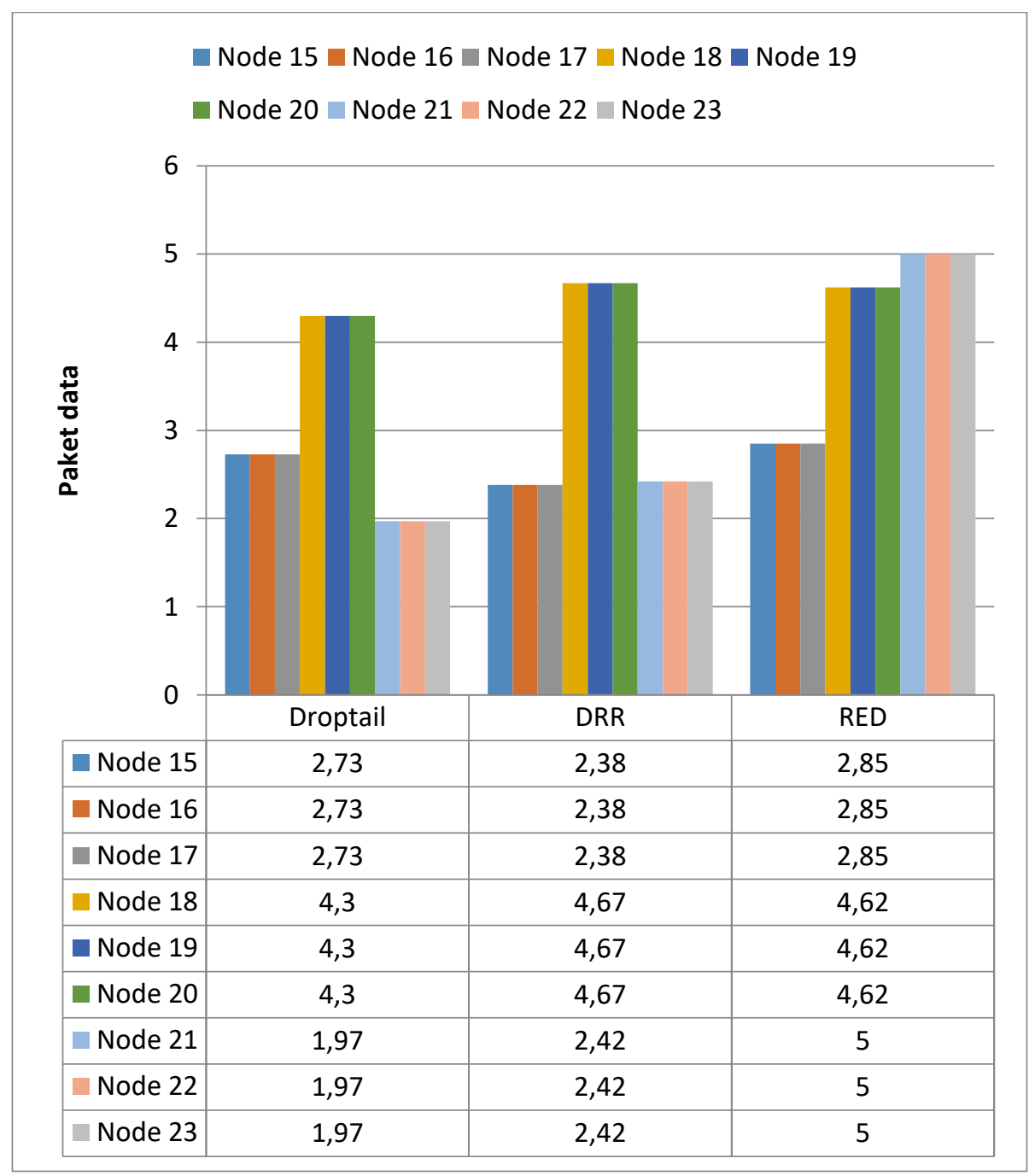

Gambar 24. Perbandingan rata-rata packet loss scenario 3. 


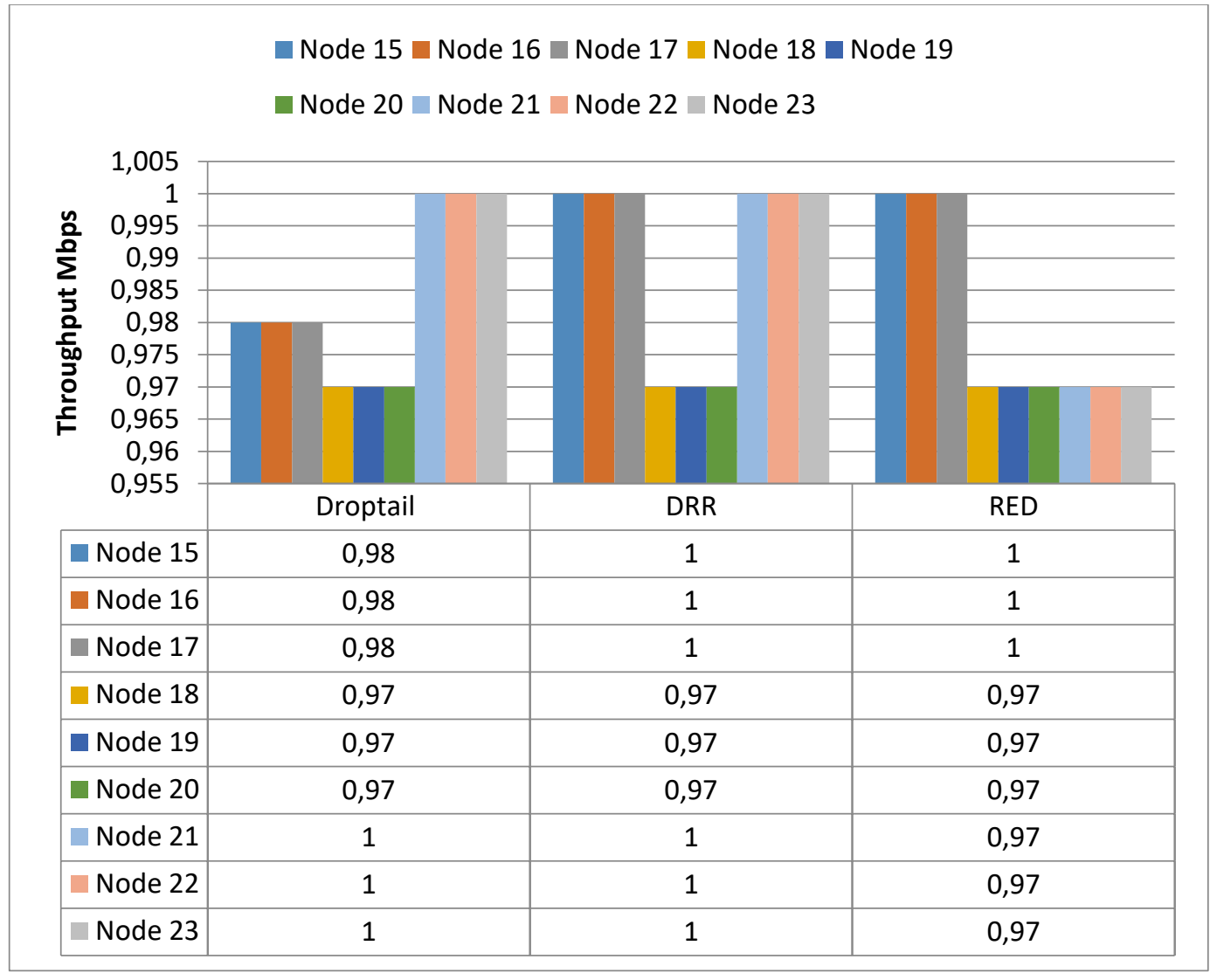

Gambar 25. Perbandingan rata-rata throughput scenario 3.

\subsubsection{Analisa Aktifitas Queue}

Pada skenario 3, berdasarkan data pada Gambar 26 terdapat penurunan nilai throughput jika dibandingkan pengujian pada skenario 2 hal ini dikarenakan terjadi perpindahan masing-masing member multicast terhadap server multicast sehingga untuk melakukan reconnection terhadap joint server terbaru PIM-DM memerlukan waktu hingga prune state time out, selisih waktu ini yang membuat penurunan nilai mean throughput menurun. Data mean loss pada Gambar 27 membuktikan bahwa RED dengan nilai throughput yang lebih rendah mampu menekan paket loss di angka mean loss yang sama dengan DRR dan Droptail pada link 4-3 dan link 9-4.

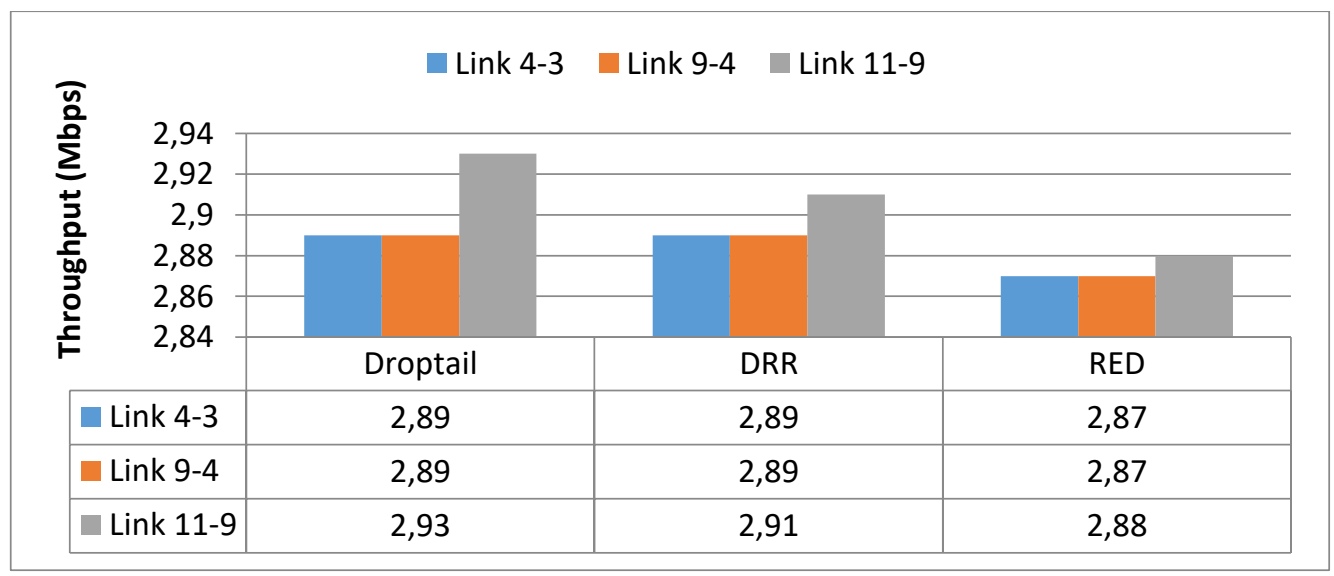

Gambar 26. Perbandingan rata-rata throughput jalur multicast. 


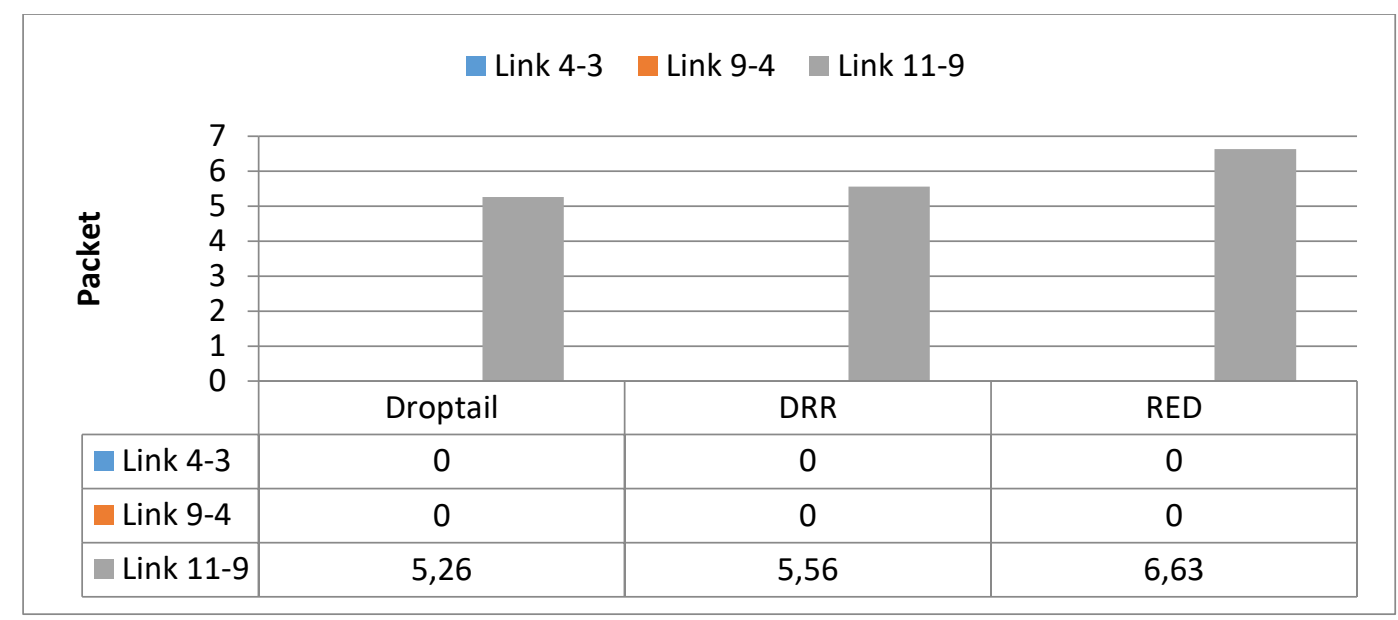

Gambar 27. Perbandingan rata-rata packet loss jalur multicast.

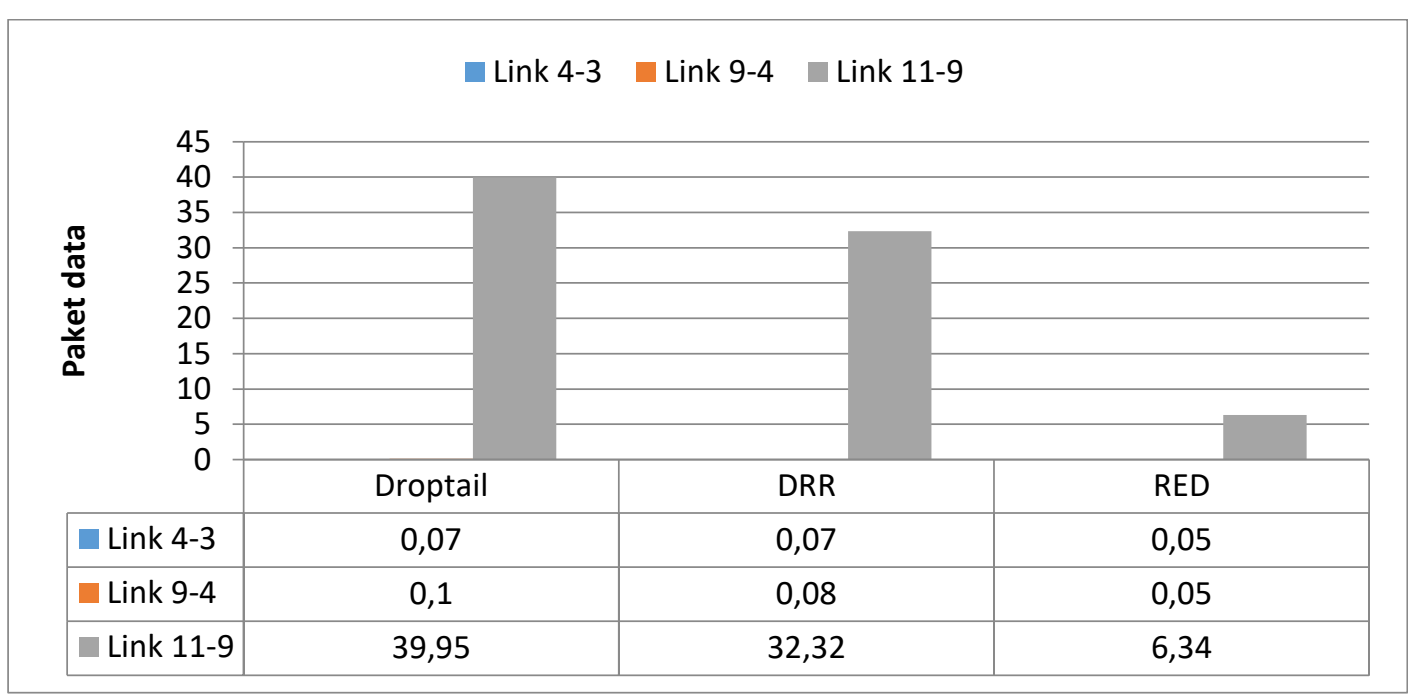

Gambar 28. Perbandingan rata-rata queue size jalur multicast.

Berdasarkan data pada Gambar 28 RED memiliki queue lost yang paling tinggi, tidak lain karena buffer size RED memang sangat kecil. Rasio buffer size per performance algoritma congestion control RED jauh lebih baik dari pada DRR maupun Droptail.

\section{Kesimpulan}

Berdasarkan penelitian yang telah dilakukan, maka dapat disimpulkan beberapa hal sebagai berikut :

1. Untuk mengukur tingkat efektifitas algoritma antrian dapat dianalisa dengan mencari perbandingan rasio queue size berbanding paket loss yang paling kecil, dimana pada penelitian ini RED memiliki algoritma penanganan congesti yang paling efisisen dengan perbandingan buffer size berbanding paket loss yang paling kecil.

2. DRR memiliki kombinasi buffer size dan metode penanganan queue yang paling baik, hal ini dapat dilihat pada pengujian skenario 1, skenario 2, dan skenario 3 DRR memiliki performance yang paling baik, dengan nilai fairness yang sangat tinggi. DRR memiliki kombinasi buffer size 
yang besar dan metode penanganan queue yang memiliki prioritas. Pada pengujian di setiap skenario DRR memiliki performance yang paling seimbang.

3. DRR dan RED memiliki mekanisme interrupt pada proses pelayanan queue-nya sehingga pelayanan queue terhadap setiap aliran data akan dilayani dengan adil.

4. Algoritma congestion control RED memiliki mekanisme pengalokasian bandwidth paling baik terhadap setiap aliran data jika dibandingkan DRR dan Droptail, hal ini dapat dilihat pada skenario 3 dimana dengan penggunaan bandwidth dengan selisih 0,02 Mbps lebih kecil pada setiap sesi RED mampu meredam paket loss pada link 9-3 dan link 4-3 dengan kuantitas yang sama dengan DRR dan Droptail.

\section{DAFTAR REFERENSI}

[1] D. Arvianto, H. Hafidudin, dan A. Rudiana, "Analisa Perbandingan Performansi Skema MultiLevel RED untuk Differentiated Services di Internet," dalam Seminar Nasional Aplikasi Teknologi Informasi (SNATI), 2007.

[2] M. Agrawal, N. Tiwari, L. A. S. Chaurasia, dan J. Saraf, "Queueing for Multisource Network'Type of Queue Decides Quality of Services of Network," dalam Proceedings of International Symposium on Computing, Communication, and Control (ISCCC 2009), 2009.

[3] B. A. Prasetiya, "Pengaruh Video Bit-Rate dan Background Traffic Terhadap Kinerja Video Streaming pada Jaringan Wireless LAN," Institut Pertanian Bogor, 2008.

[4] O. W. Purbo, A. Basalamah, I. Fahmi, dan A. H. Thamrin, TCP/IP Standar, Desain, dan Implementasi. Jakarta: Elexmedia Komputindo, 1998.

[5] T. S. Siadari, "Perancangan dan Implementasi Penyiaran Video Langsung Berbasis Web di IT TELKOM," Telkom institute of Technology, Bandung, 2009.

[6] M. Shreedhar dan G. Varghese, "Efficient fair queuing using deficit round-robin," IEEE/ACM Transactions on networking, vol. 4, no. 3, hlm. 375-385, 1996. 